\title{
Bitki Gelişimini Teşvik Eden Rizobakterilere Ait Patentlerin İncelenmesi
}

\author{
PInar SÖZER BAHADIR ${ }^{1}$, Özgür GÜVENENLER ${ }^{2}$, Rengin ELTEM ${ }^{1}$ \\ ${ }^{1}$ Ege Üniversitesi Mühendislik Fakültesi Biyomühendislik Bölümü, Bornova, İzmir \\ ${ }^{2}$ Ege Üniversitesi EBILLTEM Teknoloji Transfer Ofisi, Bornova, İzmir
}

\section{ÖZET}

Dünya çapında sürdürülebilir tarım uygulamalarına ilginin artması ile kalıntısız üretime yönelik biyolojik preparatların üretimi ve kullanımı gün geçtikçe yaygınlaşmaktadır. Bitki gelişimini teşvik eden rizobakteriler (plant growth promoting rhizobacteria; PGPR) sürdürülebilir tarım için büyük öneme sahiptir.

Yapılan çalışmaların fikri ve sınai mülkiyet haklarının korunması amacıyla, söz konusu bilimsel veri ve yöntemler, patentler vasıtasıyla dünyadaki tüm araştırmacı ve üreticilerin erişimine sunulmaktadır. Patent dökümanları ilgilenilen konuya ait içerdiği teknik, yasal ve ticari bilgiler sayesinde, en güncel teknolojik bilgi kaynağı olarak nitelendirilmektedir. Dünya çapında agrobiyoteknolojik çalışmalara olan eğilime paralel olarak, bu alandaki patent başvuruları da artış göstermiştir.

Çalışmamızda PGPR'lara ait, mikrobiyal gübre ve/veya biyokontrol etmeni olarak aktivite gösteren çeşitli mikroorganizmalar, üretim yöntemleri, ürün geliştirme amacıyla kullanılan teknikler ve çeşitli uygulamaların yer aldığı dünya çapındaki patent başvurularının taranması amaçlanmıştır. Patent tarama çalışması ile ulaşılabilen 273 adet patente ait bilgiler sınıflandırılarak grafikler ve çizelgeler ile sunulmuştur.

Anahtar sözcükler: Bitki gelişimini teşvik eden rizobakteriler, PGPR, mikrobiyal gübre, biyokontrol etmeni, patent

\section{Investigation of Patents Belongs to Plant Growth Promoting Rhizobacteria}

\begin{abstract}
Worldwide, along with the increased interest in sustainable agriculture practices, residueless oriented production of biological preparations and their use is increasing day by day. Plant growth promoting rhizobacteria (plant growth promoting rhizobacteria; PGPR) are of great importance for sustainable agriculture.

For protecting the intellectual and industrial property rights of the studies, this mentioned topic provides access of scientific data and methods to researchers and manufacturers all over the world through the patents. Techniqual, legal and commercial information of the topic releated to patent document can be considered as the most latest source of technological information. In parallel with the trend towards agro-biotechnological work around the world, patent applications in this area have also increased.

Our study aimed to screen worldwide patent applications about various microorganisms belongs to PGPR group showing activities as microbial fertilizers and/or biocontrol agents, techniques used for production and development of product and scope of various practises. Information about 273 accessible patents, attained with the patent survey is classified and presented with charts and graphs.
\end{abstract}

Key words: Plant growth promoting rhizobacteria, PGPR, microbial fertilizer, biocontrol agent, patent 


\section{GİRIŞ}

Son yıllarda tarımda organik girdilerin kullanımını hedefleyen sürdürülebilir üretim sistemlerinin geliştirilmesi önem kazanmıştır. Biyoteknolojik süreçlerle azalan kimyasal girdi sayesinde daha fazla ve sağliklı gıda üretiminin sağlanmasına yönelik çalışmalar her geçen gün artmaktadır $[6,7,26]$. $\mathrm{Bu}$ amaçla özellikle organik tarım için önemli bir potansiyele sahip mikrobiyal kaynaklar değerlendirilmektedir $[5,22,24,25]$.

Biyolojik gübre kavramı son yıllarda genişleyerek, bitki gelişimi, verim ve ürün kalitesini iyileştiren, serbest yaşayan biyokontrol etmeni veya mikrobiyal gübre olarak iş gören mikroorganizmalar için genel bir başlık altında, "bitki büyümesini teşvik eden rizobakteriler (PGPR)" terimi kullanılmaya başlanmışırı $[2,7,36]$. PGPR'ların, bitki gelişimi ve kalitesinde yaptıkları olumlu etkiler çeşitli çalışmalarda ayrıntılı olarak verilmiştir [3,7,8-10,13,14,1721,27,31,33,39,40].

$\mathrm{Bu}$ derlemede, PGPR'lar ile ilgili ulaşılabilen patentlerin, uluslararası patent sinıflandırma kriterlerine göre yer aldığı sınıflara, ilk yayınlanma tarihi esas alınarak yıllara ve başvuruların yapıldığı ülkelere (ülke orijini) göre dağılımı incelenmiştir. Bunun için geniş bir anahtar kelime listesi oluşturularak PatBase Express, EPO (European Patent Office) Espacenet, EPO Global Patent Index, WIPO (World Intellectual Property Organization) Patent Scope, Google Patents ve TPE (Türk Patent Enstitüsü) gibi çeşitli veri tabanları üzerinden tarama yapılmıştır [11,12,15,28,34,37].

Çalışmada ülkemizde PGPR'larla çalışan araştırmacıların bilimsel çalışmalarını patente dönüştürebilmeleri için var olan patentler ve patent başvurularının incelendiği bir kaynak oluşturulması amaçlanmıştır. Bu amaçla PGPR'lara ait ulaşılabilen patent/patent başvuruları; mikrobiyal gübre ve/veya biyokontrol etmeni özelliklerinin vurgulandığ 1 çalışmalar, çeşitli üretim yöntemleri ve bitki uygulamalarına göre sinıflandırılarak, organizma ile ilgili detaylar, patent konusunu içeren kısa başlık ve yayın tarihine ait patent numaralarının yer aldığı çizelgeler oluşturulmuştur.

\section{PGPR'LAR İLE İLGİLI ULAŞILABİLEN ÇEŞITLLI PATENTLER}

Uluslararası Patent Sinıflandirması (International Patent Classification, IPC) indeks sayfası, teknoloji alanlarına göre

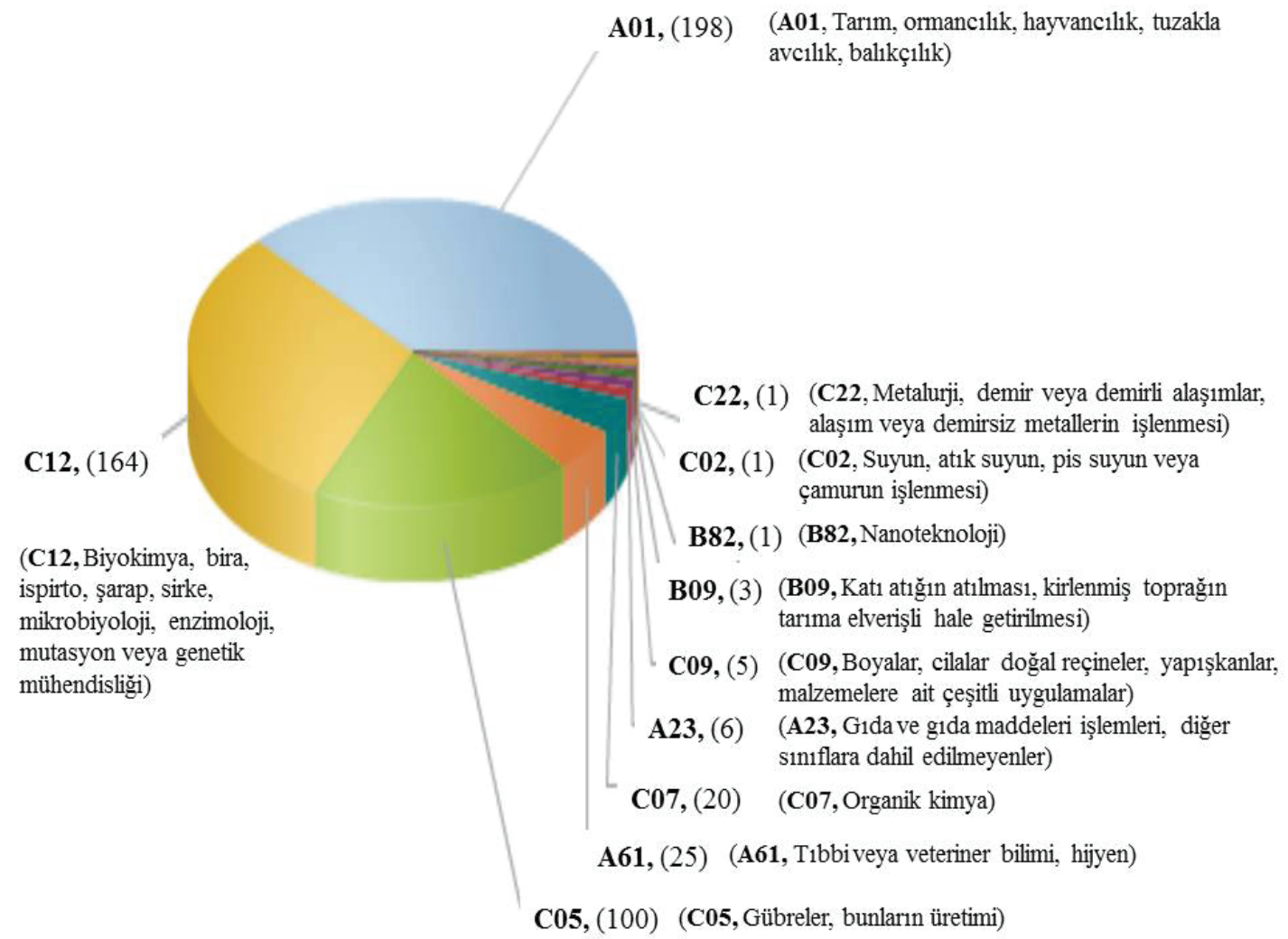

Şekil 1. Uluslararası patent sınıflandırma kriterlerine göre ulaşılabilen patentlerin yer aldığı sınıflar ve patent sayıları [11,12,15,28,34,37]. 
A'dan H'ye kadar büyük harflerle belirlenmiş 8 bölüm listesi içermektedir. IPC hiyerarşik bir sistem olup bölümler, siniflar, alt siniflar ve gruplardan (ana grup ve alt grup) oluşur. IPC'nin halen kullanılmakta olan sekizinci baskısı A dan $\mathrm{H}$ ye kadar büyük harflerden biriyle belirlenmiş sekiz bölüm altında yaklaşık 70.000 grup içermektedir [34].

PGPR'lara ait ulaşılabilen patentler incelendiğinde, A (İnsan İhtiyaçları, 223 adet) ile B (İşlemlerin Uygulanması; Taşıma, 6 adet) ve büyük çoğunluğunun da C (Kimya; Metalurji, 293 adet) bölümü altındaki sınıflarda yer aldığ tespit edilmiştir. Ulaş1labilen patentler en fazla C05F11/08 (Bakteriyel kültürler, miseller $v b$. içeren organik gübreler, 66 adet) alt grubunda yer almaktadır. Şekil 1'de incelenen patentlerin konularına göre sınıflandırma kriterleri açısından dağılımı verilmiştir. Bir patent birden fazla sınıfta yer alabilmektedir.

PGPR'larla ilgili ilk patentin (US4155737A, Çizelge 3) yayınlandığı 1979 yılı ile 2016 (02 Mart 2016) yılı arasında ulaşılabilen başvurusu yapılan, yayınlanan ve/veya tescillenen 273 adet patentin ilk yayınlanma tarihlerine bakılarak yıllara göre sayıları Şekil 2'de gösterilmiştir. Çizelge 1-4'te verilen 273 adet patentin \%46,15 (126' adet)'i tescillenmiştir. Bu patentlere ait farklı ülkeler üzerinden 1102 adet başvuru ve 373 adet patent tescili bulunmaktadır.

2014 ve 2015 yıllarında yapılan başvurular için halen süreç devam etmektedir. 2016 yılı için de iki aylık süreçte sekiz adet patent kaydı mevcuttur. Bu bilgi, 2014 yılından beri süreci devam eden patentlere aittir. Patent başvuruları, 18 aylık sürenin sonunda yayınlanarak veri tabanları üzerinden ulaşılabilir duruma gelmektedir. 2015 ve 2016 yıllarında yapılan patent başvuruları için süreç devam etmektedir.

\subsection{Patentleme Faaliyetlerinin Ülke Orijini, Kurum, Kuruluş ve Firmalar}

PGPR'larla ilgili çeşitli araştırmalara ait patentlerin yayınlanma tarihleri esas alınarak başvuru sahiplerinin fikri mülkiyet haklarını korumak istedikleri ülkelere göre yapılan sınıflandırmada sırasıyla Çin (117), Amerika Birleşik Devletleri (97), Avusturalya (73), Kanada (56), Hindis$\tan$ (45), Japonya (41), Güney Kore (39) başta olmak üzere patent sayılarının ülke orijini Şekil 3'te verilmiştir. Fikri ve sınai mülkiyet haklarını koruma altına almak isteyen araştırmacı/firma/üniversite vb. patent için birden fazla ülkeye başvuruda bulunarak buluşunu koruma altına alabilmektedir. Dünya Fikri Mülkiyet Hakları Örgütü’ne üye 184 ülkeyi temsil eden WO'ya kayitlı 127 ve Avrupa Patent Ofisine yapılan başvurulara ait Avrupa Patenti (EP)'ne kayıtlı 82 patent PGPR'larla ilgili çeşitli çalışmaları konu almaktadır. Hem Türk hem de yabancı araştırmacıların fikri ve sınai mülkiyet haklarını korumak amacıyla Türk Patent Enstitüsü'nde PGPR'larla ilgili 13 adet patent kaydına ulaşılmıştır (Şekil 3).

PGPR'lar için ulaş1labilen patentler incelendiğinde, 221 adet başvuru sahibine göre yapılan sinıflandırmada, 273 adet patentin \%41,4 (113 adet)'ü firmalara, \%39,9 (109 adet)'u araştırma merkezleri/üniversitelere ait iken \%13,2 (36 adet)'si buluşçuların bireysel başvurularına aittir. Firmaların akademik çevre ile işbirliğiyle yaptığı başvurular $\% 1,1$ (3 adet) ve buluşçuların firmalar ile işbirliği sonucunda yaptığı başvurular \%4,4 (12 adet) ile sınırlı kalmaktadır $[11,12,15,28,34,37]$.

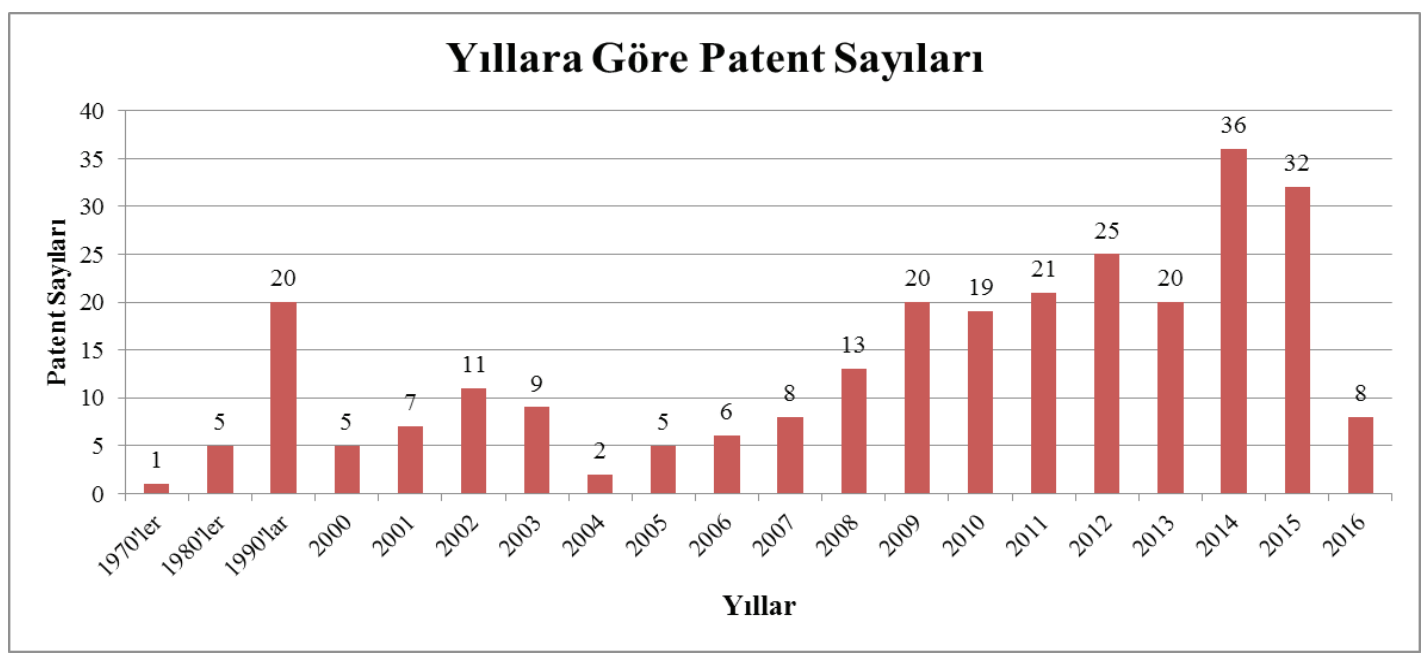

Şekil 2. PGPR'larla ilgili olarak ulaşılabilen patentlerin yayınlandığı yıllara göre sayıları [11,12,15,28,34,37]. 


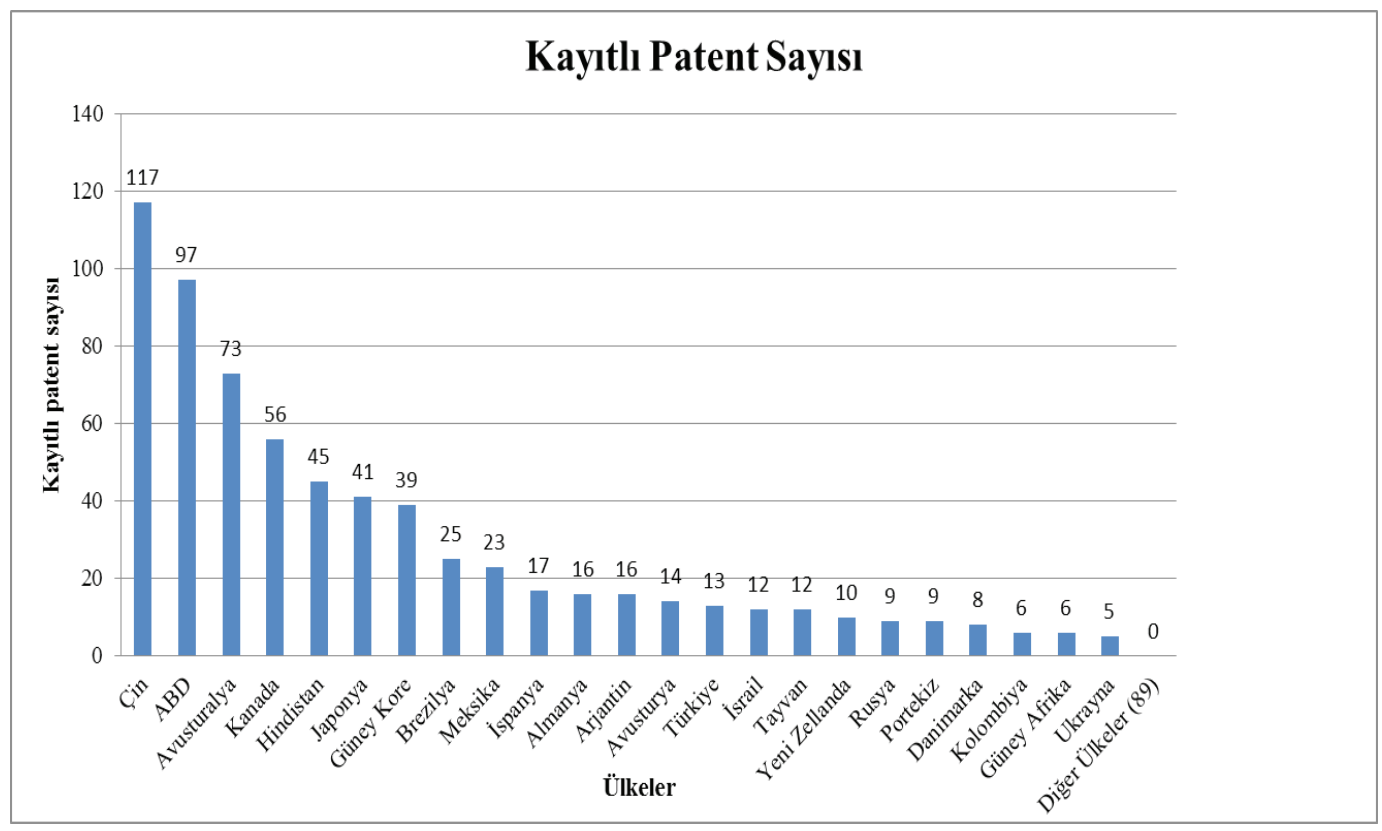

Şekil 3. Patent sayılarının ülke orijini $[11,12,15,28,34,37]$.

PGPR'lar için başvurulan/alınan patentlere rağmen, s1nırlı sayıda buluş/yenilik ticarileştirilerek piyasaya sunulmuştur. Biyoteknoloji pazarının önde gelen firmalarından Bayer Crop Science AG (US20001022968A, US2003186852A, US2012231951A, US2013142759A, US2014364309A， US2015011389A，US2015282483A), Novozymes (US2010093538A, US2014143909A), Bioorganics $^{\mathrm{TM}}$ (US4551164A, ES8608039A), Du Pont ${ }^{\mathrm{TM}}$ Nutrition Bio Sci. Aps (CN85108913A, WO15092549A3), Bioagri AB (WO9945787A1, WO0000032A1), Monsanto Technology LLC (US2014342905A), Syngenta Participations AG (US2003060496A), Basf SE (US2013017949A) ve Biocrop AG (US9187381B)'nin PGPR' larla ilgili formülasyon/üretim yöntemlerine ait çeşitli patentleri mevcuttur ve/ veya buluş sahiplerinden patent devralmışlardır. Ulaşılabilen patentlerin önemli bir kısmı Asya-Pasifik kökenli üniversite, araştırma merkezi ve firmalara aittir [11,12,15,28,34,37].

PGPR'lara ait ulaşılabilen patentlerde, Chungbuk Ulusal Üniversitesi Akademik İşbirliği Kurumu- Kore (KR20140054570A; KR100755509B; KR20100115006A; KR20100115002A; KR20100053745A; KR20100053743A), Nanjing Ziraat Üniversitesi- Çin (CN101914474A; CN102943061A; CN104357351A; CN102524303A; CN103805536A; CN104974962A; CN105112319A; US2011214463A; US2011214464A; US2011182860A; US2012045427A) ve Hindistan Tarımsal Araştırma Kurumu (IN03603CH2010A; IN04310CH2011A; IN00518DE2011A; IN01710DE2009A) patent başvuru sayısında ilk sıralardadır. Ülkemizden de Ege Üniversitesi ve Yeditepe Üniversitesi araştırmacılarının PGPR'larla ilgili çeşitli patentleri mevcuttur [11,12,15,28,34,37].

2.2 Mikrobiyal Gübre/Biyokontrol Etmeni İslevlerine Göre PGPR'lara Ait Patentler

PGPR'lar, biyolojik azot tespiti, mineral ve organik fosfat bileşiklerinin çözünürlüğü gibi bitki gelişimi için gerekli besin elementlerinin döngüsünün sağlanması, oksin (IAA; indol-3-asetik asit), giberellin, sitokinin gibi çeşitli bitkisel hormon üretimi, 1-aminosiklopropan-1-karboksilat (ACC) deaminaz enzim aktivitesi ile etilen sentezinin engellenmesi, siderofor üretimi yoluyla demir alımının artırılması, vitamin sentezi, kök geçirgenliğinin artırılması gibi doğrudan mekanizmalarla "mikrobiyal gübre" olarak bitki gelişimini ve kalitesini desteklemektedir. Ayrıca, antibiyoz, rekabet, hiperparazitizim, sistemik dayanıklılığın uyarılması, antibiyotik ve litik enzim üretimi vb. dolaylı mekanizmalarla bitki patojenlerine karşı "biyokontrol etmeni" olarak iş görmektedirler. Bununla birlikte bazı PGPR'lar da kirlenmiş topraklarda ksenobiyotiklerin biyolojik olarak bozunumunu sağlayabilmekte ve toprak agregasyonuna destek olabilmektedir $[1,4,7,16,18,23,35,38,41]$.

Mikrobiyal gübre olarak işlev gören PGPR'lara ait ulaş1labilen patentler, organizma detayları, kısa başlıkları, yayınlanma tarihi ve patent numarası bilgileriyle Çizelge 1'de verilmiştir. Ulaşılabilen patentler arasında biyokontrol etmeni özellikleri vurgulanan patentler ise Çizelge 2'de verilmiştir. 
Çizelge 1. Mikrobiyal gübre olarak işlev gören PGPR'lara ait ulaşılabilen patentler [11,12,15,28,34,37].

\begin{tabular}{|c|c|c|c|}
\hline Organizma / Detay & Kısa Başlık & Tarih & Patent \\
\hline Azospirillum brasilense SAB MKB & Bitki gelişimini iyileştiren mikroorganizmalar & 1999 & US5951978A \\
\hline $\begin{array}{l}\text { Microbispora, Streptomyces, Streptosporangiaceae, Ba- } \\
\text { cillus subtilis, Nocardiodes }\end{array}$ & $\begin{array}{l}\text { Bitki gelişimini teşvik etmek için endofitik aktinomiset- } \\
\text { ler ve onların metabolitlerini içeren karışımlar }\end{array}$ & 2007 & US2007142226A \\
\hline Bacillus megaterium & Bitki gelişiminin çok yönlü sağlanması & 2015 & RU2558291C \\
\hline $\begin{array}{l}\text { Bacillus megaterium A07, Paenibacillus barcinonensis } \\
\text { A10, } \\
\text { Pseudomonas fluoresceins N04, Bacillus cereus T11, Ly- } \\
\text { sinibacillus sphaericus T19, Paenibacillus alvei T22, Pa- } \\
\text { enibacillus alvei } 29\end{array}$ & Bitki gelişimini teşvik eden rizobakteriler ve kullanımları & 2015 & WO15114552A1 \\
\hline Serratia sp. & Bitki gelişimini teşvik eden rizobakterileri içeren karışım & 1998 & WO9844802A1 \\
\hline Enterobacter cancerogenus & $\begin{array}{l}\text { Bitki gelişimini teşvik eden rizobakteriler (PGPR) ve uy- } \\
\text { gulamaları }\end{array}$ & 2015 & CN104805045A \\
\hline Bacillus subtilis ve Chlorella sacchorophila & Mikrobiyal bitki büyüme destekleyicileri & 1985 & US4551164A \\
\hline $\begin{array}{l}\text { Escherichia } \text { sp., Bacillus subtilis, Chlorella saccharop- } \\
\text { hilia }\end{array}$ & Mikrobiyal bitki büyüme destekleyicileri & 1986 & ES8608039A \\
\hline $\begin{array}{l}\text { Escherichia sp., Bacillus subtilis, Chlorella saccharop- } \\
\text { hilia }\end{array}$ & $\begin{array}{l}\text { Mikrobiyal bitki büyüme destekleyicileri ve verim artı- } \\
\text { rıcılar }\end{array}$ & 1987 & CN85108913A \\
\hline $\begin{array}{l}\text { Pseudomonas putida, Pseudomonas fluorescens, Arthro- } \\
\text { bacter citreus, Serratia liquefaciens, Flavobacterium sp. }\end{array}$ & $\begin{array}{l}\text { Agronomik köksüz ürünler için bitki gelişimini teşvik } \\
\text { eden rizobakteriler }\end{array}$ & 1996 & US5503651A \\
\hline $\begin{array}{l}\text { Pseudomonas putida, Serratia liquefaciens, Pseudomo- } \\
\text { nas sp., } \\
\text { P.fluorescens, Arthrobacter citreus }\end{array}$ & Bitkilerde köklerde kolonize olabilen bakteriyel kültürler & 1996 & US5503652A \\
\hline Synechococcus, Halobacterium & Bitki gelişimini destekleyici inokülant & 1992 & JP4169506A \\
\hline Çeşitli suşlar* & Bitki gelişimini destekleyici inokülant & 1992 & JP4178311A \\
\hline $\begin{array}{l}\text { Azospirillum, Rhodobacter, Rhodopseudomonas, Rho- } \\
\text { dospirillum, Rhodomicrobium, Rhodopila }\end{array}$ & $\begin{array}{l}\text { Bitki gelişimini iyileştiriciler ve bitki gelişimini destek- } \\
\text { leyiciler }\end{array}$ & 1997 & JP9227322A \\
\hline Pseudomonas fluorescens LS20 (KCTC 8912P) & $\begin{array}{l}\text { Siderofor üreten yeni antagonizma türü Pseudomonas } \\
\text { fluorescens LS20 }\end{array}$ & 2000 & KR20000040193A \\
\hline $\begin{array}{l}\text { Bacillus subtilis, Saccharomyces, Lactobacillus sp., } \\
\text { asimbiyotik Azotobacterium, streptomiset, silikat bakte- } \\
\text { risi* }\end{array}$ & Biyolojik fungus gübre bileşimi & 2002 & CN1380271A \\
\hline Lactobacillus sp. & Bakteriyel büyüme artırıcı & 2007 & US2009087517A \\
\hline $\begin{array}{l}\text { Bacillus fusiformis, } \\
\text { Enterobacter pyrinus }\end{array}$ & $\begin{array}{l}\text { Bitki gelişimini teşvik eden rizobakterilerden mikrobiyal } \\
\text { inokülantlar }\end{array}$ & 2008 & PH2007000122A \\
\hline Sphingomonas sp. DZYN56 & $\begin{array}{l}\text { Hindistan sakız ağacı bitkisi rizosferinden büyüme teşvik } \\
\text { edici Azotobakter (DZYN56) ve kullanımı }\end{array}$ & 2008 & CN101319198A \\
\hline $\begin{array}{l}\text { Microbacterium phyllosphaerae ATSB31 (KACC } \\
\text { 91417P) ve Pandoraea sp.ATSB30 (KACC 91418P) }\end{array}$ & $\begin{array}{l}\text { Bitki büyümesini kaya fosfatını çözerek teşvik eden bak- } \\
\text { teriler ve bunlar kullanılarak bitki büyümesini teşvik } \\
\text { etme yöntemi }\end{array}$ & 2010 & KR20100053745A \\
\hline $\begin{array}{l}\text { Pandoraea sputorum ATSB28 (KACC 91416P) ve } \\
\text { Burkholderia kururiensis ATSB13 (KACC 91415P) }\end{array}$ & $\begin{array}{l}\text { Toprakta rizosferden izole edilen bitki büyümesin teşvik } \\
\text { eden bakteriler ve bunlar kullanılarak bitki büyümesini } \\
\text { teşvik etme yöntemi }\end{array}$ & 2010 & KR20100053743A \\
\hline Paenibacillus sp. G4 & $\begin{array}{l}\text { Potasyum bakterisi Paenibacillus sp.G4 ve bitki gelişi- } \\
\text { mini desteklemeye yönelik uygulamaları }\end{array}$ & 2014 & CN103805536A \\
\hline Bacillus megaterium ZH5 & Bacillus megaterium ve uygulamaları & 2014 & CN103992963A \\
\hline $\begin{array}{l}\text { Bacillus cereus GF1, Streptococcus thermophilus BLST, } \\
\text { Bacillus mucilaginosus G3, Bacillus subtilis B7348, Ba- } \\
\text { cillus subtilis N9135, Lactobacillus plantarum ve Can- } \\
\text { dida utilis }\end{array}$ & $\begin{array}{l}\text { Suda çözünebilen büyüme destekleyici mikrobiyal bak- } \\
\text { teri gübresi }\end{array}$ & 2015 & CN104844284A \\
\hline $\begin{array}{l}\text { Ektomikoriza, azot tespit eden bakteriler*, fosfat çözebi- } \\
\text { len bakteri*, Bacillus, Acinetobacter }\end{array}$ & İyileştirilmiş toprak gübresi & 2016 & CN105237290A \\
\hline
\end{tabular}




\begin{tabular}{|c|c|c|c|}
\hline \begin{tabular}{|l|} 
Lactobacillus plantarum \\
FERM BP2 1501 \\
\end{tabular} & $\begin{array}{l}\text { Bitki gelişimini teşvik eden inokülant ve bitki gelişimini } \\
\text { teşvik etme yöntemi }\end{array}$ & 2016 & WO16021204A1 \\
\hline Bacillus megaterium ve Bacillus mucilaginosus & $\begin{array}{l}\text { Tarımsal gübrelemede kullanılabilecek, Bacillus megate- } \\
\text { rium ve Bacillus mucilaginosus içeren biyogübre ürün- } \\
\text { leri }\end{array}$ & 2014 & WO14163472A1 \\
\hline $\begin{array}{l}\text { Bacillus subtilis, Bacillus amyloliquefaciens, Bacillus li- } \\
\text { cheniformis, Neocercomonas sp., Cercomonas sp., Van- } \\
\text { nella sp., Sandona sp., Bodomorpha sp. }\end{array}$ & Bakteriler ve protozoa içeren gübre & 2015 & WO15199541A1 \\
\hline $\begin{array}{l}\text { Saccharomyces sp., Actinomyces sp., Rhodobacter sp., } \\
\text { Bacillus sp. }\end{array}$ & $\begin{array}{l}\text { Faydalı toprak mikroorganizmaları içeren mikrobiyal } \\
\text { materyal ve hazırlama yöntemi }\end{array}$ & 2004 & KR20040006046A \\
\hline Azospirillum brasilense CW301 (KACC 91224P) & $\begin{array}{l}\text { Azot tespit etme yeteneğinde olan özgün Azospirillum } \\
\text { brasilense' nin büyüme teşvik edici etkisinin biyogübre } \\
\text { olarak kullanımı ve bu amaçla hazırlanma süreci }\end{array}$ & 2007 & KR100755509B \\
\hline Bacillus subtilis NRRL B50055 & Tarımsal kullanım için Bacillus subtilis suşu & 2009 & WO09031874A1 \\
\hline Escherichia coli DH1 ve Pseudomonas sp. BWDY42 & $\begin{array}{l}\text { Bitki büyümesini destekleyici nitrat indirgeyen mikrobi- } \\
\text { yal biyogübre karışımları }\end{array}$ & 2011 & IN00518KO2011A \\
\hline Bacillus methylotrophicus UTM401 (CGMCC No.5927) & Bacillus methylotrophicus UTM401 ve uygulamalar1 & 2012 & CN102703363A \\
\hline $\begin{array}{l}\text { Azot bakterileri*, Rhizobium spp., Metarhizium anisop- } \\
\text { liae, Beauveria bassiana, Oceanospirillales }\end{array}$ & Mikroorganizma içeren biyogübreler & 2013 & CN103351182A \\
\hline $\begin{array}{l}\text { Azot bakterileri*, Rhizobium spp., Metarhizium anisop- } \\
\text { liae, Beauveria bassiana, Oceanospirillales }\end{array}$ & $\begin{array}{l}\text { Topraktaki faydalı bakteri içeriğini artırma yeteneğindeki } \\
\text { biyogübre }\end{array}$ & 2013 & CN103351223A \\
\hline Bacillus subtilis JS & $\begin{array}{l}\text { Miscanthus (Çin kılıçotu) toprak rizosferinden izole edi- } \\
\text { len Bacillus subtilis JS suşunun bitki gelişimi destekle- } \\
\text { yen özellikleri ve kullanımı }\end{array}$ & 2014 & KR20140028777A \\
\hline $\begin{array}{l}\text { Pseudomonas veronii JS128 (KACC91746P), Pseudo- } \\
\text { monas } \\
\text { grimontii JS1215 (KACC91747P), Rhodococcus aetheri- } \\
\text { vorans JS2210 (KACC91748P) }\end{array}$ & $\begin{array}{l}\text { A ğır metallerle kirletilmiş topraklardan izole edilen arse- } \\
\text { nik direncine sahip bakteri suşunun bitki gelişimini des- } \\
\text { tekleyici özellikleri ve bu amaçla kullanımı }\end{array}$ & 2014 & KR20140054570A \\
\hline Oceanospirillales & Yeşil ferment bakteri biyogübreleri & 2014 & CN104230552A \\
\hline Mikorizal fungus* & $\begin{array}{l}\text { Mikoriza içeren özgün biyogübre karışımı üretim yön- } \\
\text { temi }\end{array}$ & 2015 & IN04055DE2012A \\
\hline Bacillus megaterium $\mathrm{X} 3$ & $\begin{array}{l}\text { Bacillus megaterium X3 suşu hazırlama yöntemi ve uy- } \\
\text { gulamas1 }\end{array}$ & 2015 & CN104928212A \\
\hline $\begin{array}{l}\text { Bacillus thuringiensis, Burkholderia vietnamiensis, } \\
\text { Burkholderia metallica, } \\
\text { Pantoea agglomerans }\end{array}$ & $\begin{array}{l}\text { Bitki gelişimini destekleyen mikroorganizmalar ve kul- } \\
\text { lanımları }\end{array}$ & 2012 & US2014342905A \\
\hline Çeşitli suşlar* & Toprak iyileştirici & 2015 & EP 2755464A4 \\
\hline Penicillium bilaii & $\begin{array}{l}\text { Bitkiler için bulunabilir fosfatın çözünürlüğünü artırmak } \\
\text { için mikrobiyal suşlar, kompozisyonlar ve yöntemler }\end{array}$ & 2014 & US2014143909A \\
\hline $\begin{array}{l}\text { Acinetobacter } \text { sp. } \\
\text { (CGMCC No.10241) }\end{array}$ & Büyümeyi teşvik eden bakteri Y40 ve uygulaması & 2015 & CN104974962A \\
\hline Bacillus subtilis $\mathrm{G} 1$ & $\begin{array}{l}\text { Bitki gelişimini teşvik eden Bacillus subtilis G1 uygu- } \\
\text { laması }\end{array}$ & 2014 & CN103563996A \\
\hline $\begin{array}{l}\text { Bacillus stratosphericus } \\
\text { (CGMCC No.7622) }\end{array}$ & $\begin{array}{l}\text { Büyümeyi teşvik eden aktif 1-aminosiklopropan-1-kar- } \\
\text { boksilik asit (ACC) enzimi üreten bakteri ve uygulamas1 }\end{array}$ & 2014 & CN103642730A \\
\hline Pseudomonas Y2 & $\begin{array}{l}\text { Fosfat çözücü bakteri Pseudomonas Y2, biyoorganik } \\
\text { gübre }\end{array}$ & 2015 & CN105112319A \\
\hline Paenibacillus spp. & Bitki büyüme teşvik edici ve tuz toleransını iyileştirici & 2013 & JP2013075881A \\
\hline $\begin{array}{l}\text { Bacillus aryabhattai CAP53-CAP56, Bacillus flexus } \\
\text { BT054, Paracoccus kondratievae NC35, Enterobacter } \\
\text { cloacae CAP12, Bacillus nealsonii BOBA57 }\end{array}$ & $\begin{array}{l}\text { Bitki gelişimini teşvik eden bakteriler ve kullanım yön- } \\
\text { temleri }\end{array}$ & 2014 & US2014274691A \\
\hline
\end{tabular}

*: Türü belirtilmeyen mikroorganizmalar. 
Çizelge 2. Biyokontrol etmeni olarak işlev gören PGPR'lara ait ulaşılabilen patentler [11,12,15,28,34,37].

\begin{tabular}{|c|c|c|c|}
\hline Organizma/Detay & Kısa Başlık & Tarih & Patent \\
\hline $\begin{array}{l}\text { Pseudomonas spinosa }(\mathrm{Lkm} / \mathrm{B} / 2) \text {, Pseudomonas putida } \\
(\mathrm{Lkm} / \mathrm{B} / 1 ; \mathrm{Lkm} / \mathrm{B} / 35 ; \mathrm{Lkm} / \mathrm{B} / 76 \mathrm{c}), \text { Burkholderia gladi- } \\
\text { oli }(\mathrm{Lkm} / \mathrm{B} / 4), \text { Burkholderia } \mathrm{spp} \text {. }\end{array}$ & Biyokontrol etmeni olarak mikrobiyal formülasyonlar & 2005 & MY135549A \\
\hline Bacillus spp., Serratia sp. & $\begin{array}{l}\text { Biyokontrol etmeni olarak mikrobiyal inokülant PSX'in } \\
\text { toprak kökenli bazı hastalıklara karşı çeşitli bakteri kom- } \\
\text { binasyonları }\end{array}$ & 2009 & US2011182860A \\
\hline Coniothyrium minitans CM2004 & $\begin{array}{l}\text { Biyokontrol etmeni Coniothyrium minitans CM2004 su- } \\
\text { şunun Sclerotinia sclerotiorum ve } S \text {. minor'un neden ol- } \\
\text { duğu hastalıkları önlemek amacıyla hazırlanması ve uy- } \\
\text { gulaması }\end{array}$ & 2011 & CN102234619A \\
\hline Coniothyrium minitans $\mathrm{CHY} 1 \mathrm{C} 1$ & $\begin{array}{l}\text { Biyokontrol etmeni Coniothyrium minitans CHY1C1 su- } \\
\text { şunun Sclerotinia sclerotiorum ve } S \text {. minor'un neden ol- } \\
\text { duğu hastalıkları önlemek için hazırlanması ve uygula- } \\
\text { ması }\end{array}$ & 2010 & CN102408995A \\
\hline Myxamoebae & Amoeba ve biyokontrol amaciyla kullanımı & 2014 & US2014056850A \\
\hline Bacillus subtilis TRB3 & Tütünde siyah kök çürüklüğüne karşı biyokontrol suşu & 2012 & CN102747013A \\
\hline Çeşitli suşlar* & $\begin{array}{l}\text { Toprak hastalıklarının etkilerini baskılama yeteneğindeki } \\
\text { tarımsal materyal }\end{array}$ & 1999 & JP11092320A \\
\hline $\begin{array}{l}\text { Trichoderma, Fusarium, Penicillium, Saccharomyces ve } \\
\text { Gliocladium }\end{array}$ & $\begin{array}{l}\text { Bitki hastalıklarını kontrol eden inokülant ve hastalığ1 } \\
\text { kontrol yöntemi }\end{array}$ & 2003 & JP2003192515A \\
\hline $\begin{array}{l}\text { Paenibacillus sp. BS0048, Paenibacillus sp. BS0074, } \\
\text { Paenibacillus polymyxa BS0105 ve Paenibacillus sp. } \\
\text { BS0277 }\end{array}$ & $\begin{array}{l}\text { Paenibacillus genusuna ait özgün suşların bitki hastalık- } \\
\text { larını kontrol yöntemi veya kültürü }\end{array}$ & 2007 & US2007248583A \\
\hline Bacillus amyloliquefaciens MJ3 & $\begin{array}{l}\text { Bitki gelişimi teşvik edici antifungal rizobakteri Bacillus } \\
\text { amyloliquefaciens MJ3'ün kullanılmas1 }\end{array}$ & 2006 & KR20060021162A \\
\hline Çeşitli suşlar* & $\begin{array}{l}\text { Biyokontrol amaciyla çeşitli bakteriler ve biyokontrol et- } \\
\text { meni bakterileri içeren organik gübreler }\end{array}$ & 2015 & CN103518781B \\
\hline Sphingobacterium ematocida ZY711 & $\begin{array}{l}\text { Kök ur nematodunun biyokontrolünde görevli mikroor- } \\
\text { ganizma ve uygulamas1 }\end{array}$ & 2011 & CN102212498A \\
\hline Bacillus sp. (CGMCC No.9689) & $\begin{array}{l}\text { Nematot öldüren sfingozin, Bacillus suşu ve uygulama- } \\
\text { ları }\end{array}$ & 2015 & CN104450560A \\
\hline Burkholderia sp., Bacillus sp. & $\begin{array}{l}\text { Toprak mikrobiyal gübreleri olarak özgün Bacillus sp. ve } \\
\text { Burkholderia sp. }\end{array}$ & 2006 & KR100592540B** \\
\hline Clonostachys rosea $(8710)$ & $\begin{array}{l}\text { Bitki canlılığı, sağlığı, büyüme ve verimin iyileştirilmesi; } \\
\text { zararlıların kontrolünde kimyasal kullanımına bağlı çev- } \\
\text { resel stresin azaltılması için özgün inokülant olarak endo- } \\
\text { fitlerin üretimi ve kullanılması }\end{array}$ & 2009 & US2009105076A** \\
\hline Pseudomonas spp. & Pseudomonas bakterileri & 2010 & US2010093538A** \\
\hline $\begin{array}{l}\text { Bacillus pumilus } \\
\text { (CCTCC No. M2010143) }\end{array}$ & $\begin{array}{l}\text { Endomikoriza destekçi Bacillus pumilus ve uygulama } \\
\text { yöntemi }\end{array}$ & 2010 & CN101914474A** \\
\hline $\begin{array}{l}\text { Bacillus cereus } \\
\text { (CGMCC No.4991) }\end{array}$ & $\begin{array}{l}\text { Bitki gelişimini teşvik edici rizobakteri olarak Bacillus } \\
\text { cereus ve uygulaması }\end{array}$ & 2012 & CN102321554A** \\
\hline Bacillus licheniformis & Antimikrobiyal aktiviteye sahip Bacillus licheniformis & 2012 & KR20120063581A \\
\hline Bacillus spp. & $\begin{array}{l}\text { Büyüme, bitki sağlı̆̆ının desteklenmesi ve hastalık ve za- } \\
\text { rarlıların kontrolü ile zımpara kağıdı inciri (sand paper } \\
\text { fig) bitkisinin gelişiminin iyileştirilmesi amacıyla mutant } \\
\text { Bacillus'a ait yöntemler }\end{array}$ & 2012 & US2012231951A** \\
\hline Trichoderma harzianum (HAN12) & $\begin{array}{l}\text { Trichoderma harzianum (HAN12) suşu ve kök boğazı } \\
\text { yanıklığına karşı bitkiyi korumaya yönelik uygulamaları }\end{array}$ & 2012 & CN102719364A \\
\hline Bacillus amyloliquefaciens (CGMCC No. 6676) & $\begin{array}{l}\text { Bitki gelişimini destekleyen bakteri ve fungisit olarak uy- } \\
\text { gulamas1 }\end{array}$ & 2014 & CN103820348A \\
\hline
\end{tabular}




\begin{tabular}{|c|c|c|c|}
\hline Bacillus amyloliquefaciens (CGMCC No. 6676) & $\begin{array}{l}\text { Bitki gelişimini destekleyen bakteri ve fungisit olarak uy- } \\
\text { gulamas1 }\end{array}$ & 2014 & CN103820349A \\
\hline Bacillus subtilis EB045 (KACC91355P) & $\begin{array}{l}\text { Özgün antifungal ve büyüme teşvik eden ve biyopesti- } \\
\text { sit Bacillus subtilis EB045 (KACC91355P) bakterisinin } \\
\text { sıvı üreme ortamı }\end{array}$ & 2009 & KR20090125978A** \\
\hline Gluconacetobacter & $\begin{array}{l}\text { Gluconacetobacter suşunun bitki gelişimini teşvik etmek } \\
\text { amaciyla kullanılması }\end{array}$ & 2015 & CN105132332A** \\
\hline Serratia plymuthica (A 153) & $\begin{array}{l}\text { Yeni bakteriyel izolat, hazırlanma yöntemi ve aktif bile- } \\
\text { şenlerinin kullanımı }\end{array}$ & 2003 & US2003130121A \\
\hline Penicillium bilaii & $\begin{array}{l}\text { Bir fosfat çözücü mikroorganizma ve fungisidal aktif bi- } \\
\text { leşen içeren bileşikler }\end{array}$ & 2013 & US2013017949A \\
\hline $\begin{array}{l}\text { Meira geulakonigae } \\
\text { (CBS 110052), Meira argovae (CBS 110053) ve Aca- } \\
\text { romyces ingoldii (CBS 110050) }\end{array}$ & $\begin{array}{l}\text { Çeşitli fungus türleri ve bunların zararlılarla mücadele ve } \\
\text { hastalıkların kontrolünde kullanılması }\end{array}$ & 2005 & US2005119125A \\
\hline $\begin{array}{l}\text { Aspergillus oryzae, Aspergillus sojae (NRRL 21368, } \\
\text { NRRL 21369, NRRL 21882, NRRL 30038, NRRL } \\
\text { 30039) }\end{array}$ & $\begin{array}{l}\text { Ürünlerde aflatoksin kontaminasyonunun kontrolü için } \\
\text { toksijenik olmayan Aspergillus flavus suşu }\end{array}$ & 2012 & US2012183507A \\
\hline Pichia anomala, Candida oleophila, Ulocladium atrum & Biyopestisit kompozisyonları & 2004 & US2004096428A \\
\hline $\begin{array}{l}\text { Lactobacillus parafarraginis, L. buchneri, L. rapi, } \\
\text { L. zeae, L. casei, L. paracasei }\end{array}$ & $\begin{array}{l}\text { Antimikrobiyal aktivite ve biyokontrol özelliği olan bak- } \\
\text { teriyel suşlar }\end{array}$ & 2014 & WO14172758A1 \\
\hline Metarhizium sp. & Toprak kökenli zararlıların biyolojik kontrolü & 2002 & WO02087344A1 \\
\hline Bacillus pumilus QST2808 & Nematotların biyokontrolü & 2013 & US2013142759A \\
\hline Trichoderma atroviride SC1 & $\begin{array}{l}\text { Bitkilerdeki fungal hastalıkların biyokontrolü için Tri- } \\
\text { choderma atroviride } \mathrm{SC1}\end{array}$ & 2011 & US2011020286A \\
\hline Paecilomyces carneus & Paecilomyces ile fitoparazitik nematotların biyokontrolü & 2015 & US2015342199A \\
\hline Lactobacillus casei & $\begin{array}{l}\text { Fırsatçı patojen enfeksiyonlarının tedavisinde kullanıl- } \\
\text { mak üzere biyokontrol etmenleri }\end{array}$ & 1997 & WO9736603A1 \\
\hline Cryptococcus flavescens & $\begin{array}{l}\text { Fusarium solgunluğunun biyokontrolü için protiyokona- } \\
\text { zol'e toleranslı Cryptococcus flavescens suşlarının kul- } \\
\text { lanımı }\end{array}$ & 2011 & US2011027233A \\
\hline M.anisopliae ve mutant E.coli & Biyokontrol mikroorganizmaları & 2012 & US2012263690A \\
\hline Paenibacillus alvei (TS15) & $\begin{array}{l}\text { Paenibacillus alvei (TS15) ve ürünlerdeki patojenik or- } \\
\text { ganizmaların kontrolünde kullanımı }\end{array}$ & 2014 & US2014322168A \\
\hline Aspergillus flavus & Toksijenik olmayan Aspergillus flavus suşu & 2014 & WO14191917A1 \\
\hline Trichoderma asperellum & $\begin{array}{l}\text { Phytophthora ramorum 'un istila ettiği topraklardan gide- } \\
\text { rilmesinde Trichoderma asperellum'un kullanımı }\end{array}$ & 2015 & US2015056169A \\
\hline $\begin{array}{l}\text { Pseudomonas spp. (KI72, AB131, KI 353, MF41, MA } \\
\text { 358) }\end{array}$ & Özgün biyokontrol etmenleri & 2000 & WO0000032A1 \\
\hline Sphaerodes mycoparasitica & $\begin{array}{l}\text { Fusarium ve diğer patojenik funguslar ve mikotoksin bi- } \\
\text { yokontrolü }\end{array}$ & 2012 & US2012156173A \\
\hline $\begin{array}{l}\text { Paenibacillus macerans, Pseudomonas putida Sporobo- } \\
\text { lomyces roseus }\end{array}$ & $\begin{array}{l}\text { Bitkilerde Paenibacillus macerans, Pseudomonas pu- } \\
\text { tida, Sporobolomyces roseus ile biyokontrol }\end{array}$ & 2002 & US2002028228A \\
\hline Bacillus amyloliquefaciens FZB42 & Bitkiler için biyolojik etmenler & 2015 & WO15092549A3 \\
\hline Verticillium lecanii & $\begin{array}{l}\text { Verticillium lecanii kullanılarak külleme hastalığının } \\
\text { kontrolü }\end{array}$ & 2003 & WO03000050A2 \\
\hline $\begin{array}{l}\text { Bacillus cereus NRRL B30517, NRRL B30519, Bacil- } \\
\text { lus amyloliquefaciens NRRL B30518, Bacillus subtilis } \\
\text { NRRL B30520 }\end{array}$ & $\begin{array}{l}\text { Patojenik fungusların biyolojik kontrolü için Bacillus } \\
\text { suşları }\end{array}$ & 2003 & US6589524B \\
\hline Pseudozyma aphidis & $\begin{array}{l}\text { Çeşitli bitki patojenlerine karş1 Pseudozyma aphidis' in } \\
\text { biyokontrol etmeni olarak kullanımı }\end{array}$ & 2013 & US2013184154A \\
\hline Pichia anomala & $\begin{array}{l}\text { Nemli tahılların depolanmasında Pichia anomala'nın bi- } \\
\text { yokontrol etmeni olarak ilavesi }\end{array}$ & 1999 & WO9945787A1 \\
\hline Bacillus spp. & Yeşil küf inhibitörü & 2009 & US2009214502A \\
\hline
\end{tabular}




\begin{tabular}{|c|c|c|c|}
\hline Bacillus sp. izolat F727 & $\begin{array}{l}\text { Antifungal, antibakteriyel ve büyüme destekleyici Bacil- } \\
\text { lus sp. suşu }\end{array}$ & 2014 & US2014128256A \\
\hline Rhizobium spp. & İnokülant toleranslı fungisidal bileşikleri & 2003 & US2003060496A \\
\hline $\begin{array}{l}\text { Bakteri suşları (NRRL B30486, NRRL B30487, NRRL } \\
\text { B30488) }\end{array}$ & $\begin{array}{l}\text { NRRL B30486, NRRL B30487, NRRL B30488 olan } \\
\text { bakteriyel suşların sinerjistik biyoinokülant kompozis- } \\
\text { yonu ve bu kompozisyonun hazırlanma yöntemi }\end{array}$ & 2003 & US2003211119A \\
\hline Bacillus methylotrophicus YC 7077 & $\begin{array}{l}\text { Endofitik Bacillus methylotrophicus YC } 7077 \text { suşu ve } \\
\text { çok fonksiyonlu biyopestisit olarak kullanımı ile mikro- } \\
\text { biyal gübre geliştirme }\end{array}$ & 2015 & WO14175496A8 \\
\hline Bacillus subtilis & Bacillus genusuna ait özgün bakteri ve kullanımı & 2016 & WO16027279A1 \\
\hline Bacillus sp. & Bitki hastalıklarının kontrolü için özgün Bacillus sp. & 2001 & $\begin{array}{l}\text { US2001022968A } \\
\text { TR200201745 }\end{array}$ \\
\hline
\end{tabular}

*: Türü belirtilmeyen mikroorganizmalar.

**: Ulaşılabilen patentler arasında hem mikrobiyal gübre hem de biyokontrol etmeni özellikleri vurgulanan patentler.

\subsection{PGPR'ların Üretim Yöntemi, Formülasyon ve Bitki Uygulamalarina Ait Patentler}

PGPR'larla ilgili araştırma-geliştirme faaliyetleri ile ürün geliştirme çabalarında mevcut teknolojilerin bilinen durumu, geliştirilen üretim yöntemleri ve çeşitli formülasyon çalışmaları patent veri tabanlarından araştırılarak ulaşlabilen patentler Çizelge 3'te verilmiştir. PGPR'larla ilgili bu patentler, çizelgede detayı verilen organizmalara ait çeşitli üretim yöntemleri, ürün geliştirmek amaciyla kullanılan yeni teknolojiler ve çalışılan çeşitli formülasyonlar olarak üç ayrı konu başlığı altında özetlenebilir. Ulaşılabilen patentler arasinda mikrobiyal gübre ve/veya biyokontrol etmeni özelliğine sahip mikroorganizmalar için bahsedilen üretim yöntemleri; PGPR özelliğine sahip mikroorganizmaların izolasyonu, suş geliştirme, mikroorganizmalara özgü üretim ortamı ve koşullarının belirlenmesine ait, özellikle düşük maliyeti hedefleyen besiyeri içeriklerinin denendiği çalışmalar ile çeşitli kokültür uygulamalarına aittir.

PGPR biyopreparatları için ürün geliştirme amacıyla yeni teknolojileri konu alan patentlerde, genetik mühendisliği çalışmaları ile geliştirilen biyoformülasyonlar (US6277625B, US2008182790A, WO09072762A2, CN102943061A, US2004139495A, US2014140961A, US2014274707A, US2015143578A) dikkat çekerken, mevcut biyoprepatların özelliklerini iyileştirmeye yönelik farklı çalışmalara (IN00399CH2012A) da rastlanmıştır. Antagonistik aktivitenin yanısıra uzun raf ömrü ve dayanıklılığın amaçlandığ 1 bir formülasyon için altın ve gümüş nanopartikül biyosentezinin çalışıldığı nanoteknolojik bir uygulama da yeni teknikler arasındadır (US2012108425A). Bakteriyel hastalıkların, yeterli çoğunluğu algılama (quorum sensing) sinyalleri ile kontrol edilmesine ait tekniğin yer aldığı patentler (US7410638B, US2008182790A) ile PGPR'ların tespiti için spesifik oligonükleotit probların geliştirilmesine ait patentli bir çalışma (EP1130115A2) da mevcuttur.

Çeşitli katkı maddelerinin (örneğin talk tozu, kitin/kitosan vb. kimyasal maddeler ile tarımsal atık ve yan ürünlerin) ilavesiyle geliştirilen formülasyonlar ve PGPR preparatlarının etkinliğini artımaya yönelik çeşitli uygulamalar (tohum kaplama, suda iyi çözünen/suda tamamen çözünen katı formlar, sıvı, emülsiyon, granül, kapsül vb.) ile amaca yönelik (örneğin alkali toprak yapısı, okaliptüs için özel biyogübre, toprak kaynaklı bitki patojeni funguslara karşı etkili) geliştirilen formülasyonlara (CN101318856A, CN101318857A, US5068105A) ait patentler çizelgede içeriklerinde yer alan organizma detayı ile birlikte verilmiştir. Formülasyon çalışmalarına ait ulaşılabilen patentlerde fungus, bakteri, maya, alg, protozoa ve aktinomisetlerin birlikte kullanıldığı patentlere de rastlanmıştır (IN00864MU2004A). 
Çizelge 3. PGPR'larla ilgili çeşitli üretim yöntemleri, kullanılan teknolojiler, geliştirilen formülasyonlar ile ilgili çalışmalara ait ulaşılabilen patentler [11,12,15,28,34,37].

\begin{tabular}{|c|c|c|c|}
\hline Organizma / Detay & Kısa Başlık & Tarih & Patent \\
\hline Azospirillum ve fosfor çözücü bakteriler* & $\begin{array}{l}\text { Bitki sistemi rizosferine etki ederek daha iyi ürün geli- } \\
\text { şimi ve tarımsal verimlilik için biyokapsül uygulama- } \\
\text { lası }\end{array}$ & 2007 & IN01451CH2007A \\
\hline Aureobasidium spp. & $\begin{array}{l}\text { Biyokontrol etmenlerinin hazırlanması, saklanması ve } \\
\text { uygulaması için yöntem }\end{array}$ & 2004 & WO04047541A1 \\
\hline Bacillus spp. & $\begin{array}{l}\text { Bitki gelişimini iyileştirmek için bileşimler ve yöntem- } \\
\text { ler }\end{array}$ & 2007 & US2007148754A \\
\hline Çeşitli suşlar* & $\begin{array}{l}\text { Toprak için elverişli mikroorganizmaların iç döngüle- } \\
\text { rini kullanarak bitki gelişiminin iyileştirilmesi yöntemi }\end{array}$ & 2007 & KR20070118044A \\
\hline $\begin{array}{l}\begin{array}{l}\text { Azot tespit edebilen, fosfat ve potasyum çözebilen } \\
\text { bakteriler* }\end{array} \\
\end{array}$ & $\begin{array}{l}\text { Biyoorganik ve yarı organik fonksiyonel gübreler ve } \\
\text { hazırlama yöntemleri }\end{array}$ & 2010 & CN101891544A \\
\hline Bacillus sp. & $\begin{array}{l}\text { Buğday ve mısırda ors tozu ve toprak kaynaklı hasta- } \\
\text { l1klara karşı fungisit olarak kullanılmak amacıyla biyo- } \\
\text { kontrol etmeni hazırlama yöntemi }\end{array}$ & 2008 & CN101485333A \\
\hline $\begin{array}{l}\text { Bacillus firmus, Bacillus cereus, Bacillus pumilus, } \\
\text { Bacillus amyloliquefaciens, Bacillus subtilis GB03, } \\
\text { Bacillus subtilis QST713 }\end{array}$ & $\begin{array}{l}\text { Fluopiram ve biyokontrol etmeni içeren aktif bileşen } \\
\text { kompozisyonu }\end{array}$ & 2013 & US2015011389A \\
\hline $\begin{array}{l}\text { Trichoderma harzianum, Trichoderma viride ve } B a \text { - } \\
\text { cillus licheniformis }\end{array}$ & $\begin{array}{l}\text { Mikrobiyal bakterisit kompoziti, hazırlama yöntemi ve } \\
\text { uygulaması }\end{array}$ & 2014 & CN102964178B \\
\hline $\begin{array}{l}\text { Azotobacter chroococcum, Azospirillum lipoferum, } \\
\text { Bacillus coagulans, Bacillus tequilensis, Bacillus li- } \\
\text { cheniformis }\end{array}$ & $\begin{array}{l}\text { Biyogübre ve biyopestisit olarak yararlı doğal PGPB } \\
\text { karışık kültürleri için teknoloji }\end{array}$ & 2013 & IN01060DE2013A \\
\hline Paecilomyces lilacinus & $\begin{array}{l}\text { Biyolojik gübre olarak Paecilomyces lilacinus 'in hazır- } \\
\text { lama yöntemi }\end{array}$ & 2010 & CN101671210A \\
\hline Bacillus megaterium ve Streptomiset & $\begin{array}{l}\text { Bitki büyümesi için bakteri inokülantı ve hazırlama } \\
\text { yöntemi }\end{array}$ & 2003 & CN1442063A \\
\hline Bacillus subtilis & $\begin{array}{l}\text { Bacillus türlerinin inokülasyonu ile bitki gelişiminin ar- } \\
\text { tırılması için karışım ve yöntemler }\end{array}$ & 2003 & US2003228679A \\
\hline Bacillus subtilis EB045 (KACC91355P) & $\begin{array}{l}\text { Özgün antifungal ve büyüme teşvik eden ve biyopesti- } \\
\text { sit Bacillus subtilis EB045 (KACC91355P) bakterisi- } \\
\text { nin s1v1 üreme ortamı }\end{array}$ & 2009 & KR20090125978A \\
\hline Burkholderia sp. & $\begin{array}{l}\text { Ağır metal direnci ve bitki gelişimini teşvik eden özel- } \\
\text { liğe sahip bakterilerin hazırlanması ve uygulama yön- } \\
\text { temi }\end{array}$ & 2010 & CN101671636A \\
\hline Trichoderma citrinoviride & $\begin{array}{l}\text { Trichoderma citrinoviride mikropropagüllerinin eko- } \\
\text { nomik bir süreç ile üretilmesi }\end{array}$ & 2014 & $\begin{array}{l}\text { WO14104998 A1 } \\
\text { US2015368673A }\end{array}$ \\
\hline Biyokontrol etmeni* & $\begin{array}{l}\text { Liyofilize biyopestisit efervesan granül ve üretim yön- } \\
\text { temi }\end{array}$ & 2010 & $\begin{array}{l}\text { WO2012035454A1 } \\
\text { US2013209372A } \\
\text { TR201007613A2 } \\
\end{array}$ \\
\hline $\begin{array}{l}\text { Burkholderia cepacia OSU-7, Bacillus megaterium } \\
\text { M-3, Bacillus subtilis OSU-142 }\end{array}$ & Biyolojik gübre ve elde edilme yöntemi & 2012 & TR201206294U \\
\hline Trichoderma harzianum & Trichoderma granül üretimi & 2009 & WO09083819A1TR200709242 A2 \\
\hline $\begin{array}{l}\text { Trichoderma harzianum, Bacillus subtilis ve Glioc- } \\
\text { ladium roseum }\end{array}$ & $\begin{array}{l}\text { Bitki ürünlerinde sürekli hastalıkların kontrolü için } \\
\text { kompozit mikrobiyal inokülantlar, hazırlama yöntem- } \\
\text { leri ve uygulamaları }\end{array}$ & 2015 & CN104531533A \\
\hline Trichoderma sp. ve Bacillus sp. & $\begin{array}{l}\text { Biyolojik olarak hastalık önlenmesinde çimenler için } \\
\text { özel kültür substratının hazırlama yöntemi }\end{array}$ & 2012 & CN102633564A \\
\hline Streptomyces sp. & $\begin{array}{l}\text { Streptomiset kullanılarak bitki gelişimini teşvik eden } \\
\text { rizosfer bakterilerinin üretim yöntemi }\end{array}$ & 2005 & CN1565197A \\
\hline
\end{tabular}




\begin{tabular}{|c|c|c|c|}
\hline Trichoderma sp. & $\begin{array}{l}\text { Mikrobiyal biyokontrol etmeni Trichoderma ile kapsül } \\
\text { formda inokülant hazırlama yöntemi }\end{array}$ & 2008 & CN101496528A \\
\hline $\begin{array}{l}\text { Pseudomonas auneofaciens Tx-1, Pseudomonas ch- } \\
\text { lononaphis } 63-28\end{array}$ & $\begin{array}{l}\text { Bitki hastalıklarının biyolojik kontrolünde ve bitki ge- } \\
\text { lişimini teşvik etmek için kullanılabilecek bakteri for- } \\
\text { mülasyonu }\end{array}$ & 2014 & US2014026258A \\
\hline Lysinibacillus sphaericus $\mathrm{TC1}$ & $\begin{array}{l}\text { Lysinibacillus sphaericus TC1 suşunun bitki hastalık- } \\
\text { larında kullanılmak için hazırlanması ve bitki hastalık } \\
\text { kontrolü }\end{array}$ & 2014 & WO14065589A1 \\
\hline $\begin{array}{l}\text { Trichoderma viride, Trichoderma hamatum, Tricho- } \\
\text { derma harzianum, Talaromyces flavus, } \\
\text { Gliocladium virens, Gliocladium roseum, Paeci- } \\
\text { lomyces fumosoroseus, Penicillium oxalicum ve La- } \\
\text { etisaria arvalis }\end{array}$ & $\begin{array}{l}\text { Toprak kaynaklı bitki patojenlerinin biyokontrolü için } \\
\text { fungal formülasyon }\end{array}$ & 1991 & US5068105A \\
\hline Bacillus subtilis & $\begin{array}{l}\text { Mikrobiyal biyokontrol etmeni olarak Bacillus subtilis } \\
\text { suşunun hazırlama yöntemi ve uygulaması }\end{array}$ & 2014 & CN104357351A \\
\hline $\begin{array}{l}\text { Simbiyotik ve simbiyotik olmayan yolla azot tespit } \\
\text { edebilen, fosfat çözebilen, potasyum hidrat mobili- } \\
\text { zasyonu yapabilen pestisidal, fungisidal ve nemato- } \\
\text { sidal mikroorganizmalar }\end{array}$ & $\begin{array}{l}\text { Bitkilerin sağlıklı büyümesi için faydalı mikroorganiz- } \\
\text { maların kapsül formları }\end{array}$ & 2011 & WO13035032A2 \\
\hline $\begin{array}{l}\text { Streptomyces spp., Trichoderma atroviride, Pseudo- } \\
\text { monas aeuroginosa }\end{array}$ & $\begin{array}{l}\text { Antogonistik aktiviteler için uzun raf ömrü ve daya- } \\
\text { nıklılığın amaçlandığı altın ve gümüş nanopartükülle- } \\
\text { rin biyosentezi }\end{array}$ & 2010 & US2012108425A \\
\hline CM biyogübre (Ticari ürün)* & Biyolojik organik gübre ve üretim yöntemi & 2015 & CN101508605A \\
\hline Lysobacterium enzymogenesis & $\begin{array}{l}\text { Genetik modifiye Lysobacterium enzymogenesis suşun } \\
\text { bitkiyi bakteriyozisten koruma yeteneği }\end{array}$ & 2013 & CN102943061A \\
\hline Bacillus subtilis JUWEI001 & Bacillus subtilis, kültür yöntemi ve uygulaması & 2013 & CN103146617A \\
\hline Bacillus subtilis SBT14 & $\begin{array}{l}\text { Bitki gelişimini teşvik eden Bacillus sp. rizobakterisi- } \\
\text { nin düşük maliyetli üretim yöntemi }\end{array}$ & 2011 & IN01155CH2010A \\
\hline Karışık kültür* & $\begin{array}{l}\text { Patojenleri önlemek ve gübre kullanımını azaltmak } \\
\text { amaciyla tohum kaplama kompozisyonu ve hazırlan- } \\
\text { ması }\end{array}$ & 2011 & IN01491DE2009A \\
\hline Paenibacillus spp. & $\begin{array}{l}\text { Pirinç tohumunda biyokontrolün iyileştirilmesi için } \\
\text { bakteriyel biyofilm oluşumu }\end{array}$ & 2012 & CN102618466A \\
\hline Çeşitli funguslar* & $\begin{array}{l}\text { Biyogübre ve biyopestisitler için büyümeyi iyileştirme } \\
\text { ve taşıyıcı geliştirilmesi amaciyla tapyoka nişastası ve } \\
\text { soya unu koformülasyonu }\end{array}$ & 2010 & IN00766DE2009A \\
\hline Çeşitli suşlar* & $\begin{array}{l}\text { Bitki gelişimini teşvik edici rizobakteri (PGPR) biyoor- } \\
\text { ganik gübreler ve üretim yöntemi }\end{array}$ & 2013 & CN102942417A \\
\hline $\begin{array}{l}\text { Pseudomonas fluroscence, Bacillus subtilis, Paeni- } \\
\text { bacillus spp., Pseudomonas putida }\end{array}$ & $\begin{array}{l}\text { Bitki gelişimini teşvik edici rizobakteriyel sıvı inokü- } \\
\text { lant }\end{array}$ & 2014 & IN00801CH2011A \\
\hline Aspergillus awamori & $\begin{array}{l}\text { Fosfat çözücü sıvı biyogübre eldesi ve hazırlanışı için } \\
\text { yöntem }\end{array}$ & 2006 & IN00356MU2006A \\
\hline Trichoderma harzianum & $\begin{array}{l}\text { Bitki hastalıklarının biyolojik kontrolünde bir fungal } \\
\text { antagonist emülsiyon formülasyonu }\end{array}$ & 2010 & IN03603CH2010A \\
\hline Fungal biyokontrol etmenleri* & $\begin{array}{l}\text { Fungal biyokontrol etmeni için tarımsal atık esaslı bü- } \\
\text { yüme ortamının formülasyonu }\end{array}$ & 2011 & IN01335DE2009A \\
\hline Azospirillum brasilense & $\begin{array}{l}\text { Azospirillum brasilense'nin kist esaslı özgün sıv1 bi- } \\
\text { yogübresi ve üretim yöntemi }\end{array}$ & 2011 & IN02004DE2010A \\
\hline Bacillus polymyxa & $\begin{array}{l}\text { Strese toleranslı sıvı biyokütlenin fosfat çözücü bakte- } \\
\text { rilerle özgün formülasyonu }\end{array}$ & 2011 & IN01547DE2010A \\
\hline İzolat UW4* & Bitki teşvik edici bakteri ve üretimi & 2009 & CN101481666A \\
\hline Trichoderma sp. & $\begin{array}{l}\text { Toprak kalitesini artırmak için buğday/pirinç atıklarının } \\
\text { mikrobiyal dekompozisyonu }\end{array}$ & 2011 & IN01925DE2010A \\
\hline
\end{tabular}




\begin{tabular}{|c|c|c|c|}
\hline Trichoderma harzianum & $\begin{array}{l}\text { Trichoderma'nın hindistan cevizi liflerinden üretim sü- } \\
\text { reci }\end{array}$ & 2011 & IN04310CH2011A \\
\hline Azotobacter chroococcum & $\begin{array}{l}\text { Azotobacter chroococcum sıv1 biyoinokülantı ve üre- } \\
\text { tim süreci }\end{array}$ & 2012 & IN00518DE2011A \\
\hline Karış1k bakteri kültürleri* & Biyokontrol formülasyonu ve üretim yöntemi & 2013 & IN00521DE2011A \\
\hline E. aranearum (JN036556) & $\begin{array}{l}\text { Patates nematot kistlerinin kontrolü için yumurta para- } \\
\text { ziti fungusun (Engyodontium aranearum) biyoformü- } \\
\text { lasyonu }\end{array}$ & 2013 & IN00399CH2012A \\
\hline Pseudomonas fluorescens LR1 & $\begin{array}{l}\text { Pseudomonas fluorescens LR1 ile iki fosfat çözücü } \\
\text { mikroorganizmadan oluşan sıv1 formülasyonun tarım- } \\
\text { sal gübrelemede kullanılmas1 }\end{array}$ & 2014 & WO14163473A1 \\
\hline Azotobacter spp. & $\begin{array}{l}\text { Biyogübre ürünü olarak kullanılabilecek iki Azotobac- } \\
\text { ter suşunun sıvı formülasyonu }\end{array}$ & 2014 & WO14163474A1 \\
\hline \begin{tabular}{|l}
$\begin{array}{l}\text { Lactobacillus, Bacillus, fotosentetik bakteri*, } \\
\text { maya* }\end{array}$ \\
\end{tabular} & $\begin{array}{l}\text { Etkili mikroorganizmalar kullanılarak bitki gelişimini } \\
\text { iyileştiren içeriğin üretim süreci }\end{array}$ & 2008 & KR20080101148A \\
\hline $\begin{array}{l}\text { Pseudomonas cedrina UW3, Pseudomonas putida } \\
\text { UW4 }\end{array}$ & $\begin{array}{l}\text { Bitki gelişimini teşvik eden bakterilerden oluşan biyo- } \\
\text { lojik preparatlar, hazırlanması ve kullanımı }\end{array}$ & 2009 & CN101497542A \\
\hline Çeşitli suşlar* & $\begin{array}{l}\text { İyileştirilen raf ömrü ile bitki geliş̧imini teşvik eden öz- } \\
\text { gün formülasyon ve hazırlanması }\end{array}$ & 2011 & IN01710DE2009A \\
\hline Pseudomonas aurantiaca & Kültür yöntemi ve uygulamaları & 2011 & CN102199558A \\
\hline $\begin{array}{l}\text { Bacillus polymyxa, Bacillus subtilis, Pseudomonas } \\
\text { putida, Pseudomonas fluorescens }\end{array}$ & $\begin{array}{l}\text { Bitki gelişimini teşvik etmek için beslenme gereksi- } \\
\text { nimini karşılamak amacıyla bakteriyel formülasyonun } \\
\text { hazırlama yöntemi ve başlıca materyaller }\end{array}$ & 2011 & WO11154962A1 \\
\hline Pseudomonas aurantiaca & $\begin{array}{l}\text { Pseudomonas aurantiaca preparat1, hazırlama yöntemi } \\
\text { ve uygulamas1 }\end{array}$ & 2012 & CN102505009A \\
\hline Microbacterium spp., ve algal kültür & Gübre kompozisyonu ve üretim yöntemi & 2012 & US2012192605A \\
\hline $\begin{array}{l}\begin{array}{l}\text { Bacillus lateraporus, Bacillus licheniformis, Chlo- } \\
\text { rella }\end{array} \\
\end{array}$ & $\begin{array}{l}\text { Bitki gelişimini iyileştirmek için mikrobiyal gübre ve } \\
\text { kültür yöntemi }\end{array}$ & 2012 & CN102617198A \\
\hline Chlorella salin, Rhodopseudomonas palustris & $\begin{array}{l}\text { Bitki gelişimini teşvik etmek için fikomisetlerin kokül- } \\
\text { tür yöntemi }\end{array}$ & 2012 & CN102628024A \\
\hline Bacillus spp., Saccharomyces cerevisiae & Bakteriyel ve fungal büyüme için besiyeri içeriği & 2014 & US2014295482A \\
\hline $\begin{array}{l}\text { Pseudomonas, Bacillus, Azospirillum, Rhizobium } \\
\text { ve Serratia }\end{array}$ & $\begin{array}{l}\text { PGPR izolasyonu ve Pseudomonas türleri ile bitki bü- } \\
\text { yümesi için indol asetik asit üretimi }\end{array}$ & 2014 & IN04455CH2012A \\
\hline $\begin{array}{l}\text { Bacillus licheniformis } \\
\text { (CGMCC No. 667) }\end{array}$ & $\begin{array}{l}\text { Fungisit olarak Bacillus licheniformis' in hazırlama } \\
\text { yöntemi ve uygulamas1 }\end{array}$ & 2014 & CN103820349A \\
\hline Piriformospora indica, Azotobacter chroococcum & $\begin{array}{l}\text { Piriformospora indica ve Azotobacter chroococcum'in } \\
\text { talk tozu ile bitki gelişimini teşvik eden formülasyon } \\
\text { çalışması }\end{array}$ & 2015 & WO15001575A9 \\
\hline Çeşitli suşlar* & $\begin{array}{l}\text { Tamamen suda çözünebilen katı biyoorganik gübrenin } \\
\text { üretim yöntemi }\end{array}$ & 2015 & CN104446930A \\
\hline Rhizobium HZ76 & $\begin{array}{l}\text { Ağır metal dayanıklılığına sahip Rhizobium ve uygu- } \\
\text { laması }\end{array}$ & 2015 & CN104498410A \\
\hline Arthrobacter woluwensis ED & $\begin{array}{l}\text { Arthrobacter woluwensis içeren immobilize bitki bü- } \\
\text { yüme teşvik edici etmen }\end{array}$ & 2015 & KR20150105548A \\
\hline Bacillus oryzicola & $\begin{array}{l}\text { Pirinç rizosferinden izole edilen özgün endofitik bak- } \\
\text { teri Bacillus oryzicola'nın doğal bitki koruma etmeni } \\
\text { ve bitki gelişimini destekleyici etmen olarak geliştiril- } \\
\text { mesi ve kullanımı }\end{array}$ & 2015 & WO15183003A1 \\
\hline Ochrobactrum sp. NW3 & \begin{tabular}{|l|} 
Bitki gelişimini teşvik eden bakterilerde suş geliştirme \\
ve biyolojik gübre olarak uygulamalarının araştırılması
\end{tabular} & 2015 & CN105112331A \\
\hline Bakteriyosin & $\begin{array}{l}\text { Bitki gelişimi ve hastalık direnci için bakteriyosinlerin } \\
\text { kullanımı }\end{array}$ & 2008 & US2008248953A \\
\hline
\end{tabular}




\begin{tabular}{|c|c|c|c|}
\hline $\begin{array}{l}\text { AMF+PGPR (Arbüsküler mikorizal fungus + bitki } \\
\text { gelişiminini teşvik edici rizobakteri) }\end{array}$ & $\begin{array}{l}\text { Arbüsküler mikorizal fungus }+ \text { bitki gelişimini teşvik } \\
\text { edici rizobakterilerin mikrobiyal inokülant kombinas- } \\
\text { yonu, hazırlama yöntemi ve geliştirilen mikrobiyal ino- } \\
\text { külant organofosfor pestisit kalıntılarının giderilmesi } \\
\text { için uygulanması }\end{array}$ & 2013 & CN103146608A \\
\hline $\begin{array}{l}104 \text { HXHXDH } 109 \sim 60 \text { aa } \sim \text { H } 169 \sim 21 \text { aa } \sim 191 \\
\text { ve } 103 \text { HXHXDH } 108 \sim 72 \text { aa } \sim \text { H } 180 \sim 21 \text { aa } \sim 202 \\
\text { bakteri genleri }\end{array}$ & $\begin{array}{l}\text { Bakteriyel suşlar, genler ve enzimler ile bakteriyel has- } \\
\text { talıkların yeterli çoğunluğu algılama (quorum sensing) } \\
\text { sinyalleri ile kontrolü }\end{array}$ & 2008 & US7410638B \\
\hline aiiA genini taşıyan bakteri patojenleri* & $\begin{array}{l}\text { Bitki patojeni bakterilerin quorum sensing sekansı ile } \\
\text { bakteriyel enfeksiyonun kontrolü }\end{array}$ & 2004 & US2004139495A \\
\hline $\begin{array}{l}104 \text { HXHXDH } 109 \sim 60 \text { aa } \sim 169 \sim 21 \text { aa } \sim 191 \\
\text { ve103 HXHXDH } 108 \sim 72 \text { aa } \sim \text { H } 180 \sim 21 \text { aa } \sim 202 \\
\text { bakteri genleri }\end{array}$ & $\begin{array}{l}\text { Bakteriyel suşlar, genler ve enzimler ile bakteriyel has- } \\
\text { talıkların quorum sensing sinyalleri ile kontrolü }\end{array}$ & 2008 & US2008182790A \\
\hline $\begin{array}{l}\text { Fungus*, maya*, aktinomiset*, protozoa*, alg* ve } \\
\text { bakteriler* }\end{array}$ & $\begin{array}{l}\text { Bir biyorafineride organik gübrenin mikrobiyal inokü- } \\
\text { lant ile iyileştirilmesi için özgün süreç }\end{array}$ & 2007 & IN00864MU2004A \\
\hline Bacillus cereus (EP1, EP2, EP3, EP5, ВР315) & $\begin{array}{l}\text { Palmiye yağ1 atığı kullanılarak biyogübre hazırlama } \\
\text { yöntemi }\end{array}$ & 2009 & WO09131265A1 \\
\hline $\begin{array}{|lll|}\text { Bacillus methylotrophicus UTM401 (CGMCC } \\
\text { No.5927) }\end{array}$ & Bacillus methylotrophicus UTM401 uygulamalar1 & 2012 & CN102703363A \\
\hline Çeşitli suşlar* & Mikrobiyal gübreler, hazırlanma yöntemi ve kullanımı & 2013 & CN102899264A \\
\hline Ektomikorizal fungus* & Mikorizal biyogübre ve hazırlanma yöntemi & 2013 & CN103449917A \\
\hline Mikorizal fungus* & $\begin{array}{l}\text { Mikoriza esaslı özgün biyogübre karışımı üretim yön- } \\
\text { temi }\end{array}$ & 2015 & IN04055DE2012A \\
\hline $\begin{array}{l}\text { Paenibacillus polymyxa M10, Azospirillum cana- } \\
\text { dense } \mathrm{B} 2 \text { ve Bacillus pumilus L13 }\end{array}$ & $\begin{array}{l}\text { Biyogübre ve biyopestisitin formülasyonu için bileşim } \\
\text { ve yöntem }\end{array}$ & 2015 & US9187381B \\
\hline $\begin{array}{l}\text { Azospirillum brasilense, Gluconacetobacter diazot- } \\
\text { rophicus, Burkholderia cepacia ve Herbaspirillum }\end{array}$ & Biyogübre hazırlama yöntemi ve kullanımı & 2016 & WO16009397A1 \\
\hline Tellürik mikroorganizmalar & $\begin{array}{l}\text { Kültüre edilen bitkilerde verimi kontrol etmek için } \\
\text { mikrobiyal süreç }\end{array}$ & 1979 & US4155737A \\
\hline Çeşitli suşlar* & Alkali toprak için sıvı gübre & 2008 & CN101318857A \\
\hline Çeşitli suşlar* & Okaliptüs için özel amaçlı gübre & 2008 & CN101318856A \\
\hline Çeşitli suşlar* & Organik sıv1 gübre & 2008 & CN101318851A \\
\hline Çeşitli suşlar* & Gübre & 2008 & CN101318852A \\
\hline Çeşitli suşlar* & $\begin{array}{l}\text { Organik gübre mikroorganizmaları ve hazırlama yön- } \\
\text { temi }\end{array}$ & 2011 & CN102079674A \\
\hline Çeşitli suşlar* & $\begin{array}{l}\text { Bitki gelişimini teşvik etmek ve gizli hastalıkların ön- } \\
\text { lenmesinde görevli biyolojik karışımlar }\end{array}$ & 2003 & US6524998B \\
\hline $\begin{array}{l}\text { Bacillus subtilis, Bacillus licheniformis, Pseudomo- } \\
\text { nas putida }\end{array}$ & Amonyum lignosülfat içeren yeni toprak aktivatörü & 2015 & WO15157865A1 \\
\hline Gliocladium sp. & Bitki hastalıklarını önlemek için yöntem & 2004 & US2004060232A \\
\hline $\begin{array}{l}\text { Ascomycete, Trichoderma atroviride klonu, Tricho- } \\
\text { derma atroviride } \mathrm{BCCM}\end{array}$ & $\begin{array}{l}\text { Yeni Trichoderma atroviride suşu, üretim ortamı ve } \\
\text { bitki gelişimi ve çimlenmeyi uyarmak amaciyla kulla- } \\
\text { nımı }\end{array}$ & 2008 & EP1876232A1 \\
\hline Virulent bakteriyofaj & Bitki hastalıklarının kontrolü ve uygulama için yöntem & 2014 & US2014140961A \\
\hline Çeşitli suşlar* & Modifiye biyokontrol etmenleri ve kullanımları & 2015 & US2015218568A \\
\hline Pochonia chlamydosporia & $\begin{array}{l}\text { Tohum kaplama yapılan nematosidal biyolojik kontrol } \\
\text { etmenlerinin kombinasyonu }\end{array}$ & 2010 & US2010034792A \\
\hline $\begin{array}{l}\text { Streptomyces sp. WYE } 20 \text { (KCTC 0341BP) ve } \\
\text { WYE } 324 \text { (KCTC 0342BP) }\end{array}$ & $\begin{array}{l}\text { Antifungal biyokontrol etmenlerinin hazırlanması ve } \\
\text { uygulanmasını içeren bir süreç }\end{array}$ & 2001 & US6280719B \\
\hline $\begin{array}{l}\text { Brevibacillius laterosporus } \\
\text { (NMI No.V12/001946, NMI No. V12/001945 ve } \\
\text { NMI No. V12/001944) }\end{array}$ & Biyokontrol kompozisyonları & 2014 & US2014086876A \\
\hline
\end{tabular}




\begin{tabular}{|c|c|c|c|}
\hline Trichoderma viride, Beauveria bassiana & $\begin{array}{l}\text { Kitinaz/proteaz enzimleri üreten çeşitli mikroorganiz- } \\
\text { maları içeren özgün kitin/demineralize dehidre kitinaz/ } \\
\text { eklem bacaklı iskeleti içeren formülasyon }\end{array}$ & 2015 & US2015366185A \\
\hline Transgenik Pseudomonas spp. & $\begin{array}{l}\text { Bitki kök hastalıklarının biyokontrolü için transgenik } \\
\text { Pseudomonas }\end{array}$ & 2001 & US6277625B \\
\hline Gliocladium virens & $\begin{array}{l}\text { Biyolojik mücadele veya kontrol amaçlı bir ürüne ait } \\
\text { üretim yöntemi }\end{array}$ & 2006 & US2006159660A \\
\hline Aspergillus flavus & $\begin{array}{l}\text { Aflatoksini azaltmak amaciyla biyokontrol etmeni fun- } \\
\text { gusun suda çözünen formülasyonu }\end{array}$ & 2009 & US2009060965A \\
\hline Bacillus spp. & Pestisidal bileşikler & 2014 & US2014228212A \\
\hline Trichoderma viride, Trichoderma harzianum & Bitki hastalıklarının biyolojik kontrolü için bileşik & 2010 & WO10064889A1 \\
\hline Actinomycetes spp. & $\begin{array}{l}\text { Toprak kökenli patojenlerin biyolojik kontrolü için ma- } \\
\text { teryal ve yöntem }\end{array}$ & 2002 & US2002000540A \\
\hline Bakteriyofajlar & $\begin{array}{l}\text { Biyokontrol etmeni içeren canlı biyolojik materyalle- } \\
\text { rin, patojenik bakterilerin önlenmesinde uygulama için } \\
\text { spreyleme aparatı ve yüzey sterilizasyon yöntemi }\end{array}$ & 2009 & WO09072762A2 \\
\hline Bacillus cereus & Enterotoksin içermeyen Bacillus & 2002 & US2002151071A \\
\hline Serratia plymuthica CCGG2742 & $\begin{array}{l}\text { Fitopatojenik fungusun kontrolü için biyofungisidal bi- } \\
\text { leşimi }\end{array}$ & 2012 & US2012107280A \\
\hline Çeşitli suşlar & $\begin{array}{l}\text { Bitki verimliliğinin artırılması için çoklu mikrobiyal } \\
\text { formülasyonlar }\end{array}$ & 2009 & US2009308121A \\
\hline $\begin{array}{l}\text { Azospirillum, Rhizobium, Azotobacter, Trichoderma } \\
\text { harzianum, T. viride, Pseudomonas fluorescens, P. } \\
\text { striate, Bacillus polymyxa, B. subtilis, Saccharom- } \\
\text { yces cerevisiae, Lactobacillus }\end{array}$ & $\begin{array}{l}\text { Tarımsal uygulamalarda geniş çaplı kullanım için mik- } \\
\text { robiyal karışım içeren biyoinokülantın özgün formülas- } \\
\text { yonu }\end{array}$ & 2012 & US2012015806A \\
\hline \begin{tabular}{|l|} 
Bacillus firmus, Bacillus cereus, Bacillus pumilus, \\
Bacillus amyloliquefaciens, Bacillus subtilis GB03, \\
Bacillus subtilis QST713
\end{tabular} & $\begin{array}{l}\text { Bacillus ve biyokontrol etmeni içeren aktif bileşenle- } \\
\text { rin kombinasyonu }\end{array}$ & 2014 & US2014364309A \\
\hline Entomopatojenik fungus & $\begin{array}{l}\text { Zararlıların kontrolü için entomopatojenik fungus içe- } \\
\text { ren formülasyon }\end{array}$ & 2015 & WO15080545A1 \\
\hline Pseudomonas syringae pv. Tagetis & $\begin{array}{l}\text { Biyokontrol etmenlerinin stabilizasyonu için granül } \\
\text { formülasyon }\end{array}$ & 2002 & US6455036B \\
\hline Çeşitli suşlar & Bir veya daha fazla patojene karşı bileşimler & 2008 & US2008160101A \\
\hline Çeşitli suşlar & İkili fungisidal veya pestisidal karışım & 2015 & US2015282483A \\
\hline Çeşitli suşlar* & $\begin{array}{l}\text { Bitki sağlığının korunmasında tarımsal zararlı ve has- } \\
\text { talıkları önlemek amacıyla koruyucu kaplama ve uygu- } \\
\text { lama yöntemi }\end{array}$ & 2009 & WO09063099A1 \\
\hline Azotobacter chroococcum Beijerinckia fluminensis & Organik mineral gübrelere biyolojik ilaveler & 2005 & US6939688B \\
\hline $\begin{array}{l}\text { Bacillus subtilis, Bacillus thuringiensis, Pseudomo- } \\
\text { nas aeruginosa, Arthrobacter, } \\
\text { Cellulomonas uda, Bacillus megaterium, Micrococ- } \\
\text { cus, Thiobacillus novellas } \\
\text { Saccharomyces cerevisiae }\end{array}$ & Çeşitli salgılar içeren gübreler & 2002 & WO0246126A1 \\
\hline $\begin{array}{l}\text { Ticari ürün (BioP } 2000 \text { Z Organik gübre; BioAgent } \\
\text { ve BioPlus) }\end{array}$ & Sıv1 organik gübre ve biyoperforasyon teknolojisi & 2001 & WO0183400A2 \\
\hline Sacchavomyces cerevisiae & Kümes hayvanı gübresi içeren biyolojik gübre & 2002 & US2002187552A \\
\hline Azospirillum brasilense & $\begin{array}{l}\text { Bitki gelişimini teşvik etmek için biyolojik gübre eldesi } \\
\text { ve kullanımı için yöntem }\end{array}$ & 2011 & US2011045976A \\
\hline $\begin{array}{l}\text { Bacillus licheniformis, B. subtilis, Pseudomonas } \\
\text { spp., Streptomyces spp. }\end{array}$ & $\begin{array}{l}\text { Biyolojik gübre üretim yöntemi ve bu yöntemle üreti- } \\
\text { len biyolojik gübre }\end{array}$ & 2012 & WO12107603A1 \\
\hline Biyokontrol etmeni* & Gübrelere biyolojik etmenlerin dahil edilmesi & 2016 & WO16007460A1 \\
\hline
\end{tabular}




\begin{tabular}{|c|c|c|c|}
\hline $\begin{array}{l}\text { Azospirillium, Skermanella, Rhodocista, Herbaspi- } \\
\text { rillium, Acetobacter diazotrophicus türlerinin tes- } \\
\text { piti }\end{array}$ & $\begin{array}{l}\text { Bitki gelişimini teşvik eden bakterilerin tür ve/veya sı- } \\
\text { nıflarının spesifik tespiti için oligonükleotit problar }\end{array}$ & 2001 & EP1130115A2 \\
\hline Bacillus vallismortis BS07M & $\begin{array}{l}\text { Bitkiye soğuğa dayanıklılık kazandırabilen ve bitki ge- } \\
\text { lişimini iyileştirebilen özgün Bacillus vallismortis ve } \\
\text { bu amaçla mikrobiyal formülasyonu }\end{array}$ & 2013 & WO13042900A2 \\
\hline Rekombinant Bacillus cereus & $\begin{array}{l}\text { Bitki köklerinde Bacillus sporlarının immobilizasyonu } \\
\text { ve bitkilerin patojenlerden korunması, bitki gelişiminin } \\
\text { iyileştirilmesi için füzyon proteinler ve uygulama yön- } \\
\text { temleri }\end{array}$ & 2014 & US2014274707A \\
\hline $\begin{array}{l}\text { Burkholderia vietnamensis G4, B. xenovorans } \\
\text { LB400, Cupriavidus taiwanensis LMG19424, } \\
\text { Rhizobium etli CFN42, Sinorhizobium meliloti } \\
\text { RMP110, B. phytogrmans PSJN, } \\
\text { C. pinatubonensis JMP134 }\end{array}$ & $\begin{array}{l}\text { Azot tespit edebilen bakteri ile bitki düzenleyici genle- } \\
\text { rinin birlikte etkisi }\end{array}$ & 2015 & US2015143578A \\
\hline Bitki gelişimini arttırıcı etkisi olan kök bakterileri* & $\begin{array}{l}\text { Perlit, zeolit ve kokopit taşıyıcılarıyla bakteriyel bi- } \\
\text { yogübre üretimi }\end{array}$ & 2012 & TR201200239U \\
\hline $\begin{array}{l}\text { Özgün bakteriyel endofitler* } \\
\text { (520 adet izolat) }\end{array}$ & $\begin{array}{l}\text { Tohuma yönelik endofit popülasyonu, bileşimi ve kul- } \\
\text { lanımı }\end{array}$ & 2015 & US2015020239A \\
\hline Tsukamurella paurometabola & Biyogübre bileşimi & 2010 & US2010300166A \\
\hline Bacillus subtilis & $\begin{array}{l}\text { Bitki hastalıklarının kontrolü için bileşimler ve yön- } \\
\text { temler }\end{array}$ & 2003 & US2003186852A \\
\hline
\end{tabular}

*: Türü belirtilmeyen mikroorganizmalar

Bugün dünyanın pek çok ülkesinde PGPR'ların bitkilerde gelişimi destekleyici ve ürün verimini ve bitki kalitesini artırıcı etkileri üzerinde çalışılmaktadır. Çizelge 4'te dünya çapında çeşitli araştırıcıların farklı bitki türleri ile
PGPR uygulamalarına ait ulaşılabilen patentler özetlenmiştir. Bunların çoğunluğunu, biyolojik kontrol amacıyla PGPR'ların kullanılmasına ait çeşitli yöntem ve uygulamalara ait patentler oluşturmaktadır.

Çizelge 4. PGPR'larla ilgili çeşitli bitkiler üzerinde yapılan çalışmalara ait ulaşılabilen patentler [11,12,15,28,34,37].

\begin{tabular}{|l|l|l|l|}
\hline Organizma / Detay & Kısa Başlık & Tarih & Patent \\
\hline Mikrobiyal inokülüm* & $\begin{array}{l}\text { Polygonum multiflorum için biyogübre hazırlama yön- } \\
\text { temi ve uygulaması }\end{array}$ & 2012 & CN103011965A \\
\hline Mikrobiyal inokülüm* & Salatalı için özel biyogübre ve hazırlama yöntemi & 2013 & CN103524228A \\
\hline $\begin{array}{l}\text { Bacillus megaterium, nitrifikasyon bakterileri*, maya* } \\
\text { ve laktik asit bakterileri* }\end{array}$ & Mikroorganizmaların paketleme ve hazırlama yöntemi & 2015 & CN105060506A \\
\hline Bacillus subtilis TRB3 & $\begin{array}{l}\text { Tütünde siyah kök çürüklüğüne karşı biyokontrol suşu } \\
\text { uygulamas1 }\end{array}$ & 2012 & CN102747013A \\
\hline $\begin{array}{l}\text { Bacillus licheniformis XGY132 } \\
\text { Domateste erken çürüklüğün kontrolü ve önlenmesi için } \\
\text { biyokontrol yeteneğine sahip suşun uygulamas1 }\end{array}$ & 2014 & CN104087541A \\
\hline $\begin{array}{l}\text { Bacillus subtilis ve Bacillus amyloliquefaciens } \\
\text { sp. (BCRC930076) Rhizoctonia sp. }\end{array}$ & $\begin{array}{l}\text { Orkide bitkilerinde büyümeyi teşvik etmek için bi- } \\
\text { yogübre kompozisyonu ve uygulamaları }\end{array}$ & 2006 & US2006154821A \\
\hline $\begin{array}{l}\text { Achromobacter piechaudii, Agrobacterium tumefaciens, } \\
\text { Stenotrophomonas maltophilia, Delftia acidovorans }\end{array}$ & $\begin{array}{l}\text { Kanolada performans1 artırmak için sülfür okside eden } \\
\text { bitki gelişimini destekleyen rizobakteriler }\end{array}$ & 2003 & US2003172588A \\
\hline Bacillus pumilus (CS23) ve Bacillus subtilis (SM16) & $\begin{array}{l}\text { Pamukta yanılık hastalığ1 ve Verticillium zararına karş1 } \\
\text { bakteri karışımı }\end{array}$ & 2012 & CN102524303A \\
\hline Bacillus firmus & $\begin{array}{l}\text { Kanola bitkisinde verimi artırmak için fosfat çözücü rizo- } \\
\text { bakteri Bacillus firmus }\end{array}$ & 2015 & US2015259260A \\
\hline
\end{tabular}




\begin{tabular}{|c|c|c|c|}
\hline Pseudomonas fluorescens VP5 & $\begin{array}{l}\text { Çay bitkisinde kırmızı kök hastalığının biyolojik kont- } \\
\text { rolü için PGPR biyoformülasyonun hazırlanması }\end{array}$ & 2012 & US2012270735A \\
\hline Toprak aktinomisetleri* & $\begin{array}{l}\text { Bir tür salatalık antraknozunun biyokontrolü için formü- } \\
\text { lasyon ve hazırlanma yöntemi }\end{array}$ & 2016 & CN105284901A \\
\hline $\begin{array}{l}\text { Çeşitli bakteri izolatları } \\
\text { (FERM BP11078, FERM BP11079, FERM BP11080 } \\
\text { FERM BP11071) }\end{array}$ & $\begin{array}{l}\text { Kavak bitkisi ve bitki tohumunun büyümesinin iyileşti- } \\
\text { rilmesi için bakteriler ve uygulama yöntemi }\end{array}$ & 2011 & US2011028321A \\
\hline Agrobacterium tumefaciens CBCN5(KACC 91459P) & $\begin{array}{l}\text { Çin lahanası bitkisi kök dokusundan bitki gelişimini iyi- } \\
\text { leştirmek için CBCN5 bakteri suşunun izole edilmesi ve } \\
\text { kullanımı }\end{array}$ & 2010 & KR20100115002A \\
\hline Agrobacterium tumefaciens CBCN5 (KACC 91459P) & $\begin{array}{l}\text { Çin lahanası bitkisi rizosferinden bitki gelişimini iyileş- } \\
\text { tirmek için CBCN5 bakteri suşunun izole edilmesi ve } \\
\text { kullanımı }\end{array}$ & 2010 & KR20100115006A \\
\hline Bacillus amyloliquefaciens HFJ7 (CGMCC No.10011) & $\begin{array}{l}\text { Süs biberinde büyümenin teşvik edilmesi için Bacillus } \\
\text { amyloliquefaciens bakteriyel gübresinin hazırlama yön- } \\
\text { temi ve uygulamaları }\end{array}$ & 2015 & CN104877937A \\
\hline $\begin{array}{l}\text { Bacillus subtilis, Bacillus licheniformis, Bacillus late- } \\
\text { rosporus, fotosentetik bakteri* ve aktinomiset* }\end{array}$ & $\begin{array}{l}\text { Biyolojik gübrenin bitki kök gelişimi içini iyileştirmek } \\
\text { için hazırlanma yöntemi }\end{array}$ & 2015 & CN105085040A \\
\hline Glomus (Arbusküler mikoriza) & $\begin{array}{l}\text { Domates fidelerinde büyüme ve gelişim için mikroorga- } \\
\text { nizma karışımı ve uygulaması }\end{array}$ & 2016 & CN105296366A \\
\hline Trichoderma sp. ve Bacillus sp. & Çimende büyümeyi destekleyici bileşen ve referans geni & 2005 & KR20050032646A \\
\hline Bacillus firmus & $\begin{array}{l}\text { Fosfat çözücü Bacillus firmus'un kolza bitkisinde verimi } \\
\text { artırmak için biyogübre olarak kullanımı }\end{array}$ & 2016 & UY35585A \\
\hline Çeşitli suşlar* & Zencefil için organik üretim amaçlı gübre & 2008 & CN101318850A \\
\hline Trichoderma harzianum & $\begin{array}{l}\text { Trichoderma harzianum sporlarının kanola bitkisine uy- } \\
\text { gulanması yöntemi }\end{array}$ & 2009 & TR200908397A2 \\
\hline $\begin{array}{l}\text { Pseudomonas putida, Pseudomonas fluorescens, } \\
\text { Arthrobacter citreus, Serratia liquefaciens, Flavobacte- } \\
\text { rium sp. }\end{array}$ & $\begin{array}{l}\text { Agronomik köksüz ürünler için bitki gelişimini teşvik } \\
\text { eden rizobakteriler }\end{array}$ & 1996 & US5503651A \\
\hline Trichoderma harzianum & $\begin{array}{l}\text { Mantarlarda yeşil küf hastalığına karşı biyokontrol et- } \\
\text { meni }\end{array}$ & 1998 & US5762928A \\
\hline Aspergillus flavus & $\begin{array}{l}\text { Ürünlerde aflatoksin kontaminasyonunun kontrolü için } \\
\text { toksijenik olmayan Aspergillus flavus suşu }\end{array}$ & 2012 & US2012183507A \\
\hline Gliocladium roseum ACM941 (ATCC 74447) & $\begin{array}{l}\text { Bitkilerde fungal patojenlerin kontrolünde yararlı Glioc- } \\
\text { ladium roseum suşları }\end{array}$ & 2002 & US6495133B \\
\hline Bakteri izolatı* S2HA & $\begin{array}{l}\text { Patateste kahverengi kök hastalığının kontrolünde bir bi- } \\
\text { yokontrol etmeni S2HA }\end{array}$ & 2006 & WO06069588A2 \\
\hline Phoma spp. & $\begin{array}{l}\text { Yabani otların kontrolü için fungal izolatlar ve biyolojik } \\
\text { kontrol bileşikleri }\end{array}$ & 2005 & US2005079978A \\
\hline Ascochyta caulina & Yabani otların biyokontrolü & 1996 & WO9624250A1 \\
\hline Pyricularia setariae 94904A & Fungal patojen ile yabani otların kontrolü & 2005 & US2005054530A \\
\hline Brevibacillus brevis NJL25, Bacillus cereus NJL14 & $\begin{array}{l}\text { Tütünde Fusarium 'un neden olduğu hastalıkların (sol- } \\
\text { gunluk) önlenmesinde ve giderilmesinde antagonistik } \\
\text { bakteri ve mikrobiyal organik gübresi }\end{array}$ & 2012 & US2012045427A \\
\hline Brevibacillus brevis NJL25, Bacillus cereus NJL14 & $\begin{array}{l}\text { Muzda Fusarium 'un neden olduğu hastalıkların (solgun- } \\
\text { luk) önlenmesinde ve giderilmesinde antagonistik bakteri } \\
\text { ve mikrobiyal organik gübresi }\end{array}$ & 2011 & US2011214463A \\
\hline Trichoderma harzianum SQRT037 & $\begin{array}{l}\text { Karpuz ve salatalıkta hastalıkların (solgunluk) önlenme- } \\
\text { sinde ve giderilmesinde antagonistik bakteri ve mikrobi- } \\
\text { yal organik gübresi }\end{array}$ & 2011 & US2011214464A \\
\hline $\begin{array}{l}\text { Bacillus polymyxa, Bacillus subtilis, Pseudomonas pu- } \\
\text { tida, Pseudomonas fluorescens }\end{array}$ & $\begin{array}{l}\text { Bitki gelişiminin desteklenmesi için besinsel gereksinim- } \\
\text { lerin karşılanması amacıyla özgün bakteri içerikli ürün- } \\
\text { lerin hazırlanması }\end{array}$ & 2011 & WO11099024A1 \\
\hline Bacillus subtilis & $\begin{array}{l}\text { Bitki hastalıklarının ve kök kurdunun kontrolü için öz- } \\
\text { gün Bacillus suşu }\end{array}$ & 1999 & TR9902765 T2 \\
\hline
\end{tabular}




\begin{tabular}{|l|l|c|c|}
\hline Lysobacterium enzymogenesis, Flavobacterium sp. & $\begin{array}{l}\text { Rizobakteri içeren karışım ya da bakteriyel uçucu bileşen } \\
\text { 2,4-diterbütilfenol ile antraknozun ve meyvede sararma } \\
\text { yapan fitofitora kök çürüklüğ̈ hastalığının kontrolü ve } \\
\text { aynı zamanda olgunlaşmanın uyarılmas1 }\end{array}$ & 2012 & KR220120101253A \\
\hline Frateuria, Pseudomonas, Stenotrophomonas, Bacillus & $\begin{array}{l}\text { Bitki gelişimini teşvik eden rizobakterilerin okaliptüse } \\
\text { aşllanma süreci }\end{array}$ & 2002 & WO02063946A1 \\
\hline Fosfat çözebilen bakteri* & $\begin{array}{l}\text { Fakir topraklardaki bitkilerin büyümesini teşvik etmek } \\
\text { için fosfat çözücü bakteri inokülasyon yöntemi }\end{array}$ & 2014 & CN103718690A \\
\hline Bacillus subtilis (FB17) & Bitki sağlı̆̆ının iyileştirilme yöntemi & 2010 & US2010260735A \\
\hline $\begin{array}{l}\text { Trichoderma, Penicillium, Leclercia, Pantoea, Enteroba- } \\
\text { cter, Serratia, Bacillus, Penicillium, Gliocladium, Tala- } \\
\text { romyces, Pseudomonas }\end{array}$ & Bitki hastalıklarının kontrolü & 2003 & JP22003034607A \\
\hline Agrobacterium vitis F2/5 & Kök uru hastalığının biyolojik kontrolü & 2002 & US2002090354A \\
\hline Xylella fastidiosa & $\begin{array}{l}\text { Xylella fastidiosa'nın zararlı suşları ile virülent suşlarının } \\
\text { neden olduğu hastalığın çapraz koruma ile biyokontrolü }\end{array}$ & 2005 & US2005053584A \\
\hline Cryptococcus albidus & Meyve hastalıklarının kontrolü için yöntem ve bileşik & 1998 & WO9831229A1 \\
\hline
\end{tabular}

*: Türü belirtilmeyen mikroorganizmalar.

\section{SONUÇ VE ÖNERILER}

Bilginin korunmasını amaçlayan patent sisteminin temel hedefi, yeni buluşların teşvik edilmesiyle buluş sahiplerinin cesaretlendirilmesi bu yolla bilim ve teknolojinin gelişiminin önünün açılabilmesi ve toplumsal refaha katkı sağlamaktır.

Araştırma-geliştirme ve inovasyonun ilk adımı patent araştırmalarıdır. Bir ürün geliştirme ve ar-ge çalışması planlandığında, çeşitli patent veri tabanlarında araştırma yapılması ile zaman ve para kaybının önüne geçebilir. Teknolojik ve bilimsel araştırmalarda tekrarları önlemek ve kaynak israfina engel olmak için patent araştırmaları sonucunda elde edilecek patent bilgisine başvurulmalıdır.

Konvansiyonel tarımda amaçlanan verime ulaşabilmek için kimyasal gübre, pestisit, insektisit, herbisit gibi girdilerin kullanımı bir sorun zincirini beraberinde getirirken, bunun etkilerinin her geçen gün artması ise üreticileri, girdi maliyeti ve işletmenin sürdürülebilirliği noktasında yol ayrımına getirmiştir. Tarımsal üretimde verim kayıplarına neden olan faktörlerin biyoteknolojik çözümü için, mikrobiyal gübreler ve biyokontrol etmenleri geliştirilerek, laboratuvar, sera, tarla veya doğal üreme koşullarında test edilmeli ve bunların ticari üretimleri gerçekleştirilmelidir.

Yakın gelecekte, tarımda bitki büyümesini teşvik eden rizobakteriler (PGPR)' in tüm dünyada daha da önem kazanması beklenmektedir. Günümüzde kullanım, üretim ve ticaretinin sınırlı olması ve en önemlisi de etkinliklerinin ortaya çıkarılmasındaki çalışmaların yetersizliği yüzünden istenen seviyeye ulaşılamamıştır. Mikrobiyal biyopreparatların tüketildiği ülkelere bakıldığında, bunların gelişmiş ülkeler olduğu görülmektedir. Dolayısıyla bir ülkenin gelişmişliğinin göstergelerinden biri de, insan sağlığı ve çevreye olan duyarlılığıdır. Bu tür ürünlerin üretiminin ise daha çok Uzakdoğu ve Asya ülkelerinde gerçekleştirildiği, bu ülkelerin bu alanda biyoteknolojik faaliyetlerine hız kazandırdığı görülmektedir. PGPR'lerin, mikrobiyal gübre ve biyokontrol etmeni olarak kullanımlarında, avantaj ve dezavantajlar ile yoğun (entansif) tarımdaki potansiyelleri ve gelecekleri halen araştırmaya açıktır.

Geliştirilen ürün/yönteme ait teknik bilgilerin yaklaşık \%80'ninin patent dökümanlarında bulunması sebebiyle, ticari ürünler için yapılacak patent taraması sonuçları, firmalar için de bir çeşit fuar niteliğindedir. Ülkemizden Simbiyotek Biyolojik Ürünler firması, "Trichoderma granül üretimi" başlıklı WO09083819A1 (TR200709242A2) yayın numaralı patenti ile geliştirdiği mikrobiyal gübre özellikleri ön plandaki ürünün, üretim yöntemini ve TR200908397A2 yayın numaralı "Trichoderma harzianum sporlarının kanola bitkisine uygulanması yöntemi” patenti ile de geliştirdikleri biyoformülasyonun bitki denemesine ait bilgilerinin fikri ve sınai mülkiyet haklarını korumaya almıştır.

Patent taraması ile ulaşılabilen patentleri ülkemiz açısından değerlendirdiğimizde, bu alanda patent sayılarının yeterli seviyeye ulaşamadığı görülmektedir. Ülkemizde çeşitli araştırma gruplarının, PGPR'larla ilgili çok sayıda bilimsel çalışması mevcuttur. Fakat bu alanda ulaşılabilen patent başvuruları sınırlıdır. Ege Üniversitesi'nden Prof. Dr. Rengin Eltem, Doç. Dr. Sayıt Sargın, Prof. Dr. Fazilet Vardar Sukan, Seçil Sözer'in "Trichoderma citrinoviride mikropropagüllerinin ekonomik bir süreç ile üretimi" (WO14104998A1 /US2015368673A) ve Dr. Emek Aslan, Prof. Dr. Fazilet Vardar Sukan, Prof. Dr. Hatice Özaktan'ın 
"Perlit, zeolit ve kokopit taşıyıcılarıyla bakteriyel biyogübre üretimi" (TR201200239U) başlıklı patentli çalışmaları mevcuttur. Yeditepe Üniversitesi'nden de Dr. M. Müge Yazıc1, Prof. Dr. Fikrettin Şahin, Yrd. Doç. Gülengül Duman'ın "Liyofilize biyopestisit efervesan granül ve üretim yöntemi" (WO2012035454A1/ US2013209372A/ EP11763990/ 201007613A2) ve Prof. Dr. Fikrettin Şahin, Dr. M. Müge Yazıc1, Yrd. Doç. Gülengül Duman, Prof. Dr. Metin Turan, Prof. Dr. Medine Güllüce'nin "Biyolojik gübre ve elde edilme yöntemi” (TR201206294U) çalışmasının fikri mülkiyet hakları koruma altındadır.

Patent istatistikleri, bir ülkenin inovasyon konusunda yerini görebilmesi için fikir vermektedir. Türkiye'nin biyoteknoloji bilgi altyapısı ve teknolojisi konularında zayıf yönlerinden biri de bilimsel çalışmaların yeterince patente dönüşememesidir. Ülkemiz 21. yüzyılda vakit kaybetmeden dünyadaki gelişmeleri takip ederek kendi ekonomisine katkıda bulunacak biyoteknolojik uygulama alanları üzerinden stratejik planlarla ilerlemek zorundadır. Ülkemizin bu konudaki en güçlü yönü, teknoloji transfer ofisleri (TTO) ve devletin patent destekleri ile araştırmacıların önünü açmasıdır.

Gıda güvenliği, çevre sorunları, tarımda ekonomik girdilerin artı̧̧ı gibi sorunlara getirilecek çözümlerde bitki gelişimini teşvik eden mikroorganizmalar gün geçtikçe önem kazanmaktadır. Bu noktada, tüm araştırmacılara, hem özel sektör, hem de üniversitelerimiz ve 48 adet devlet tarımsal araştırma merkezine büyük görevler düşmektedir [32].

$\mathrm{Bu}$ derleme çalışması ile ulaşılabilen patent verilerinden elde ettiğimiz patent haritaları ile PGPR'ların ülkemizde ve Dünya çapındaki durumu için bir bakış açısı kazandırma amaçlanmıştır. Fakat PGPR'lara ait patent dökümanlarının bu alandaki ilgili literatürün sadece bir kısmını oluşturduğu göz önünde bulundurulmalıdır.

\section{TEŞEKKÜR}

Çalışmanın patent taraması aşamasında desteklerinden dolay1 Ege Üniversitesi, EBİLTEM-TTO Patent Ofisi'ne teşekkürlerimizi sunarız.

\section{KAYNAKLAR}

[1] Ahemad, M. ve Khan, M.S. (2011). Functional aspects of plant growth promoting rhizobacteria: recent advancements. Insight Microbiology, 1(3), 39-54.

[2] Antoun, H. ve Prevost, D. (2006). Ecology of plant growth promoting rhizobacteria. In: PGPR: Biocontrol and Biofertlization, Z. A. Siddiqui (ed.),. Springer, The Netherlands, s. $1-38$.
[3] Aslantaş, R., Çakmakçı, R. ve Şahin, F. (2007). Effect of plant growth promoting rhizobacteria on young apple tree growth and fruit yield under orchard conditions. Scientia Horticulturae, 111, 371-377.

[4] Bashan, Y. ve Holguin, G. (1998). Proposal for the division of plant growth-promoting rhizobacteria into two classifications: Biocontrol-PGPB (plant growth-promoting bacteria) and PGPB. Soil Biology and Biochemistry, 30, 1225-1228.

[5] Bashan, Y., Puente, M.E., de-Bashan, L.E. ve Hernandez, J.P. (2008). Environmental uses of plant growth-promoting bacteria. In: Plant-microbe interactions. C. Clement (ed.), Trivandrum, Kerala, India, s. 69-93.

[6] Bhardwaj, D., Ansari, M. W., Sahoo, R. K. ve Tuteja, N. (2014). Biofertilizers function as key player in sustainable agriculture by improving soil fertility, plant tolerance and crop productivity. Microbial Cell Factories. (Open Acess) 13:66.

[7] Bhattacharyya, P.N. ve. Jha, D.K. (2012). Plant growth-promoting rhizobacteria (PGPR): Emergence in agriculture. World Journal of Microbiology and Biotechnology, 2, 13271350.

[8] Canbolat, M., Bilen, S, Çakmakçı, R., Şahin, F. ve Aydın, A. (2006). Effect of plant growth promoting rhizobacteria and soil compaction on barley seedling growth, nutrient uptake, soil properties and rhizosphere microflora. Biology and Fertility of Soils, 42, 350-357.

[9] Çakmakçı, R. (2005). Bitki gelişimini teşvik eden rizobakterilerin tarımda kullanımı. Atatürk Üniversitesi Ziraat Fakültesi Dergisi, 36 (1), 97-107.

[10] Çakmakçı, R., Erat, M., Oral, B., Erdoğan, U., Şahin, F., 2009. Enzyme activities and growth promotion of spinach by indole-3-acetic acid-producing rhizobacteria. Journal of Horticultural Science and Biotechnology, 84(4), 375-380.

[11] EPO Espacenet, http://worldwide.espacenet.com, (March 2016).

[12] EPO Global Patent Index, http://www.epo.org/searching/subscription/gpi.html, (March 2016).

[13] Ercişli, S., Eşitken, A. ve Şahin, F. (2004). Application of exogenous IBA and inoculation with Agrobacterium rubistimulate adventitious root formation among stem cuttings of two rose hip genotypes. Horticultural Science, 39, 533-534.

[14] Eşitken, A., Pırlak, L., Turan, M. ve Şahin, F., 2006. Effects of floral and foliar application of plant growth promoting rhizobacteria (PGPR) on yield, growth and nutrition of sweet cherry. Scientia Horticulturae, 110, 324- 327.

[15] GooglePatents, http://www.google.com/patents (March 2016).

[16] Govindasamy, V., Senthilkumar, M., Magheshwaran, V., Kumar, U., Bose, P., Sharma, V. ve Annapurna, K. (2010). Bacillus and Paenibacillus spp.: Potential PGPR for sustainable agriculture. In: Plant Growth and Health Promoting Bacteria. D.K. Maheshwari (ed.), Springer-Verlag, Berlin Heidelberg, s. 333-364. 
[17] Güneş, A., Ataoğlu, N., Turan, M., Eşitken, A. ve Ketterings, Q.M. (2009). Effects of phosphatesolubilizing microorganisms on strawberry yield and nutrient concentrations. Journal of Plant Nutrition and Soil Science, 173, 385-392.

[18] Hayat, R., Ali, S., Amara, U., Khalid, R. ve Ahmed, I. (2010). Soil beneficial bacteria and their role in plant growth promotion: A review. Annals of Microbiology, 60(4), 579-598.

[19] Karlıdağ, H., Eşitken, A., Turan, M. ve Şahin, F. (2007). Effects of root inoculation of plant growth promoting rhizobacteria (PGPR) on yield, growth and nutrient element contents of leaves of apple. Scientia Horticulturae, 114, 16-20.

[20] Kotan, R., Şahin, F., Demirci, E. ve Eken, C. (2009). Biological Control of the potato dry rot caused by Fusarium species using PGPR strains. Biological Control, 50, 194-108.

[21] Kumar, A., Prakash, A. ve Johri, B.N. (2011). Bacillus as PGPR in crop ecosystem. In: Bacteria in Agrobiology: Crop Ecosystem, D.K. Maheshwari (ed.), Springer-Verlag, Berlin, Heidelberg, s. 37-59.

[22] Lawai T. E. ve Babalola, O.O. (2014). Relevance of biofertilizers to agriculture. Journal Human Ecology. 47, 35-43.

[23] Lucy, M., Reed, E. ve Glick, B.R. (2004). Application of free living plant growth-promoting rhizobacteria. In: Antonie van Leeuwenhoek, Kluwer Academic Publishers, Netherlands, s. $1-25$.

[24] Mahdi, S., Hassan, S., Samoon, G.I., Rather, S.A., Dar, H.A. ve Zehra, B. (2010). Bio-fertilizers in organic agriculture, Journal of Phytology, 2(10), 42-54.

[25] Mishra, D.J., Rajvir, S., Mishra, U.K. ve Kumar, S.S. (2013). Role of bio-fertilizer in organic agricultre: A review. Research Journal of Recent Sciences. 2(ISC-2012), 39-41.

[26] Nakkeeran, S., Fernando, W.G. ve Siddiqui, Z.A. (2005). Plant growth promoting rhizobacteria formulations and its scope in commercialization for the management of pests and diseases. In: PGPR: Biocontrol and Biofertilization. Siddiqui, Z.A. (ed.), Springer, Netherlands, s. 257-296.

[27] Orhan, E., Eşitken, A., Ercişli, S. ve Şahin, F. (2007). Effects of indole 3-butyric acid (IBA), bacteria and radicletip-cutting on lateral root induction in Pistacia vera. Journal of Horticultural Science \& Biotechnology, 82, 2-4.

[28] PatBase Express, https://www.patbase.com (March 2016).
[29] Ramiraz, L.E.F. ve Mellado, J.C. (2006). Bacterial Biofertilizers. In: PGPR: Biocontrol and Biofertilization. Siddiqui, Z.A. (ed.), Springer, Netherlands, s. 143-172.

[30] Saharan, B.S. ve Nehra, V. (2011). Plant growth promoting rhizobacteria: a critical review. Life Sciences and Medicine Research. LSMR-21.

[31] Şahin, F., Çakmakçı, R. ve Kantar, F. (2004). Sugar beet and barley yields in relation to inoculation $\mathrm{N}_{2}$-fixing and phosphate solubilizing bacteria. Plant Soil, 265, 123-129.

[32] T.C. Gıda Tarım ve Hayvancılık Bakanlığ gov.tr/TAGEM/Link/13/Enstituler (July 2016).

[33] Turan, M, Güllüce M. ve von Wiren N. (2012). Yield promotion and phosphorus solubilization by plant growth-promoting rhizobacteria in extensive wheat production in Turkey. Journal of Plan Nutrition and Soil Science, 75, 818-826.

[34] Türk Patent Enstitüsü, http://www.tpe.gov.tr/ (March 2016).

[35] Verma, J.P., Yadav, J., Tiwari, Lavakush, K. N. ve Singh, V. (2010). Impact of plant growth promoting rhizobacteria on crop production. International Journal of Agricultural Research, 5, 954-983.

[36] Vessey, J. K. (2003). Plant growth promoting rhizobacteria as biofertilizers. Plant and Soil, 255, 571-586.

[37] WIPO Patent Scope,- http://patentscope.wipo.int (March 2016).

[38] Wu, C. H., Wood, T. K., Mulchandani, A. ve Chen, W. (2006). Engineering plant-microbe symbiosis for rhizoremediation of heavy metals. Applied and Environmental Microbiology, 72(2), 1129-1134.

[39] Yildırım, E., Turan, M., Ekinci, M., Dursun, A., Çakmakçı, R. (2011). Plant growth promoting rhizobacteria ameliorate deleterious effect of salt stress on lettuce. Scientific Research and Essays, 6, 4389-4396.

[40] Zahir, Z.A., Muhammad, A. ve Frankenberger, W. T. (2004). Plant growth promoting rhizobacteria: applications and perspectives in agriculture. Advances in Agronomy, 81, 97-168.

[41] Zhuang, X., Chen, J., Shim, H. ve Bai, Z. (2007). New advances in plant growth-promoting rhizobacteria for bioremediation. Environment International, 33(3), 406-413. 